Review

\title{
Advances in Metal Additive Manufacturing: A Review of Common Processes, Industrial Applications, and Current Challenges
}

\author{
Ana Vafadar*(D), Ferdinando Guzzomi, Alexander Rassau (D) and Kevin Hayward \\ School of Engineering, Edith Cowan University, Joondalup, WA 6027, Australia; f.guzzomi@ecu.edu.au (F.G.); \\ a.rassau@ecu.edu.au (A.R.); kevin.hayward@ecu.edu.au (K.H.) \\ * Correspondence: a.vafadarshamasbi@ecu.edu.au; Tel.: +61-86-304-4685
}

Citation: Vafadar, A.; Guzzomi, F.; Rassau, A.; Hayward, K. Advances in Metal Additive Manufacturing: A Review of Common Processes, Industrial Applications, and Current Challenges. Appl. Sci. 2021, 11, 1213. https://doi.org/10.3390/app11031213

Academic Editor: Namhun Kim Received: 10 January 2021

Accepted: 22 January 2021

Published: 28 January 2021

Publisher's Note: MDPI stays neutral with regard to jurisdictional claims in published maps and institutional affiliations.

Copyright: (c) 2021 by the authors. Licensee MDPI, Basel, Switzerland. This article is an open access article distributed under the terms and conditions of the Creative Commons Attribution (CC BY) license (https:// creativecommons.org/licenses/by/ $4.0 /)$.

\begin{abstract}
In recent years, Additive Manufacturing (AM), also called 3D printing, has been expanding into several industrial sectors due to the technology providing opportunities in terms of improved functionality, productivity, and competitiveness. While metal AM technologies have almost unlimited potential, and the range of applications has increased in recent years, industries have faced challenges in the adoption of these technologies and coping with a turbulent market. Despite the extensive work that has been completed on the properties of metal AM materials, there is still a need of a robust understanding of processes, challenges, application-specific needs, and considerations associated with these technologies. Therefore, the goal of this study is to present a comprehensive review of the most common metal AM technologies, an exploration of metal AM advancements, and industrial applications for the different AM technologies across various industry sectors. This study also outlines current limitations and challenges, which prevent industries to fully benefit from the metal AM opportunities, including production volume, standards compliance, post processing, product quality, maintenance, and materials range. Overall, this paper provides a survey as the benchmark for future industrial applications and research and development projects, in order to assist industries in selecting a suitable AM technology for their application.
\end{abstract}

Keywords: metal additive manufacturing; 3D printing; advanced manufacturing systems; industrial applications

\section{Introduction}

Additive manufacturing (AM) or three-dimensional (3D) printing is a manufacturing process that enables fabrication of objects by successively printing layer upon layer guided by a digital 3D model [1,2]. This unique feature allows the manufacture of complex geometries that are almost impossible to fabricate using conventional systems. Therefore, AM is a tool resource that enables designers to create custom or intricate models in one-step without conventional manufacturing limitations such as high material waste, difficulty to manufacture complex shapes, and the need for specialised tooling. Accordingly, through the use of AM, engineers have increased 'design freedom' [3]. Furthermore, part counts can be reduced and consequently, assembly time and cost are reduced or eliminated [4]. In addition, parts can be manufactured on demand, which improves response time, shortens supply chain(s), reduces storage needs, eliminates delivery costs, and decreases lead-time for critical replacement parts [3]. Wohlers et al. [5] concluded that it is expected that the AM industry growth continues over the next few years, and the sale of AM is predicted to exceed AU\$22.9 (US\$15.8) billion worldwide by industry sectors. According to the data published by Wohlers et al. [5], Figure 1 represents the distribution of AM revenues for the end-market in 2018, and represents the diverse industrial adoption of AM. 


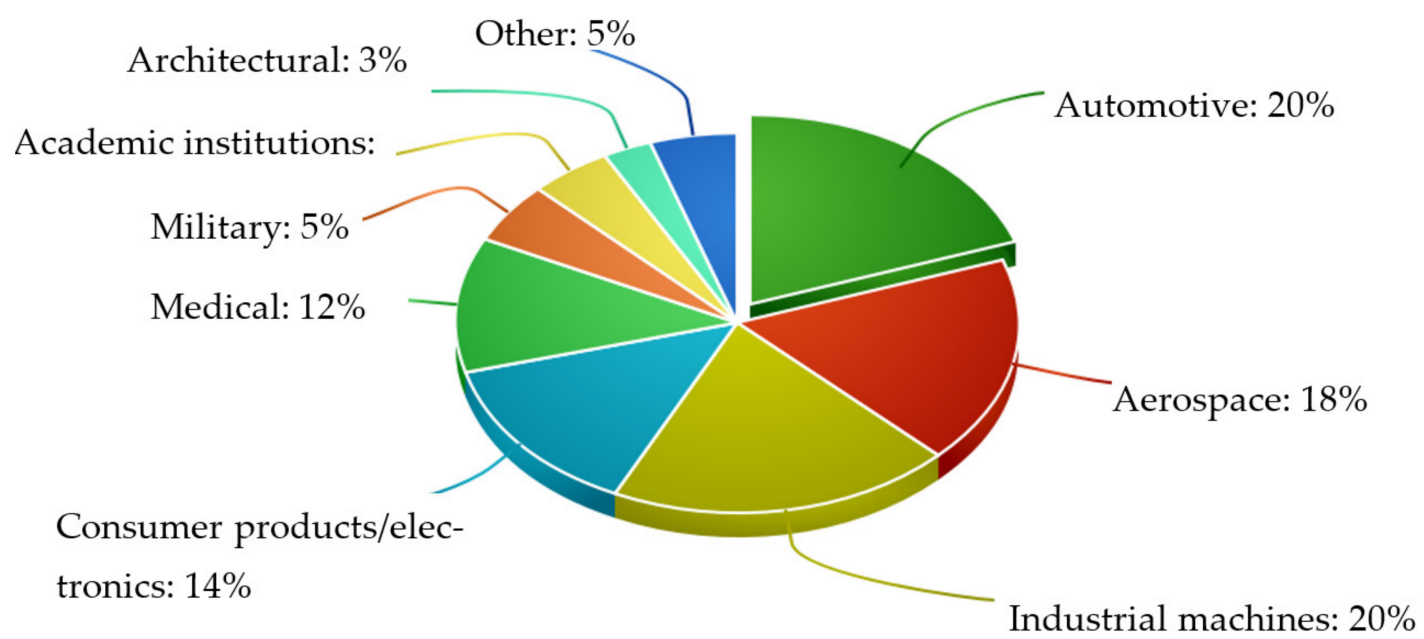

Figure 1. Industrial Adoption of additive manufacturing (AM).

AM technologies can use various materials including polymers, ceramics, and metals. Among these materials, metallic materials are gaining an increased interest from researchers and industries. In addition to the above mentioned benefits, metal AM may provide some environmental advantages such as less wastage, quality improvement, less pollutant emissions, and making parts on demand [6,7]. While metal AM provides these benefits, the extent of utilisation of metal AM technologies in industry is currently limited to a few industry sectors such as dental [8], construction [9], and aerospace [10]. In addition, researchers have generally focused on the investigation of a narrow set of metal AM processes. For instance, Ahn [11] reviewed different direct metal AM processes and addressed constraints related to applications of them. Pan et al. [12] introduced arc welding AM processes and reviewed mechanical properties of metallic materials such as Titanium alloy. Ziaee and Crane [13] presented a review of binder jetting processes, materials, and current technologies. Some researchers focused only on the material properties of metal AM products. For instance, DebRoy et al. [14] introduced microstructures, defects, and mechanical properties of metallic printed materials. Yakout et al. [15] reviewed the effects of key printing parameters on the mechanical properties and microstructure of several metallic materials such as Titanium, Aluminium, and Nickel-based alloys. Additionally, DebRoy et al. [16] reviewed metal AM materials, particularly refractory alloys, precious metals, and compositionally graded alloys.

From the above, it can be seen that the metal AM has been widely published from a material development point of view by different researchers; however, the application and suitability of different metal AM require further investigation. Clearly, an overview that introduces all of the most recent common metal AM processes and provides a wider exploration of industry applications, limitations, and challenges is required.

The aim of this study is to present a comprehensive review of the current state of metal AM, in particular introducing the most common processes, examining industrial applications across different industry sectors, exploring recent advancements, and outlining current challenges and limitations. To achieve these goals, the research and industrial data that was mainly published between 2010 and 2020 was used. This data includes metal AM magazines, high-quality research articles, industrial publications, international standards and widely accepted reports such as Wohlers and General Electrics. On the basis of this data, the most widely used metal AM processes were identified, the new advancements that were not widely known were extracted, the successful industrial applications were recognised and results were discussed, the most common metal AM challenges in different industrial sectors were identified and the considerations were discussed accordingly. Moreover, the research needed for more widespread use of metal AM in a variety of industry sectors and research and development projects were extracted from these findings and discussed in this paper. 


\section{AM Categories and Common Metal AM Processes}

AM processes fall into seven categories [17], defined by the American Society for Testing and Materials (ASTM) International Committee F42 as described in Table 1. It should be noted that commercial applications of all seven groups exist in the metal AM market. According to the published data by Cherdo [18], Figure 2 represents the diverse industrial adoption of metal AM processes in 2020. According to this figure, only five processes are commonly used for metals as discussed in the following sections. The metal AM processes are classified based on the feedstock format and thermal source. Different existing feedstock formats include wire, filament, sheet, powder, and liquid. The thermal trajectory of each process and the amount of energy required are determined by the material compounds, chemistry and transformation energetics [16]. Table 1 shows seven AM Categories and summarises common metal AM processes. This table also summaries manufacturers of common metal AM technologies, materials, and the pros and cons of each process.

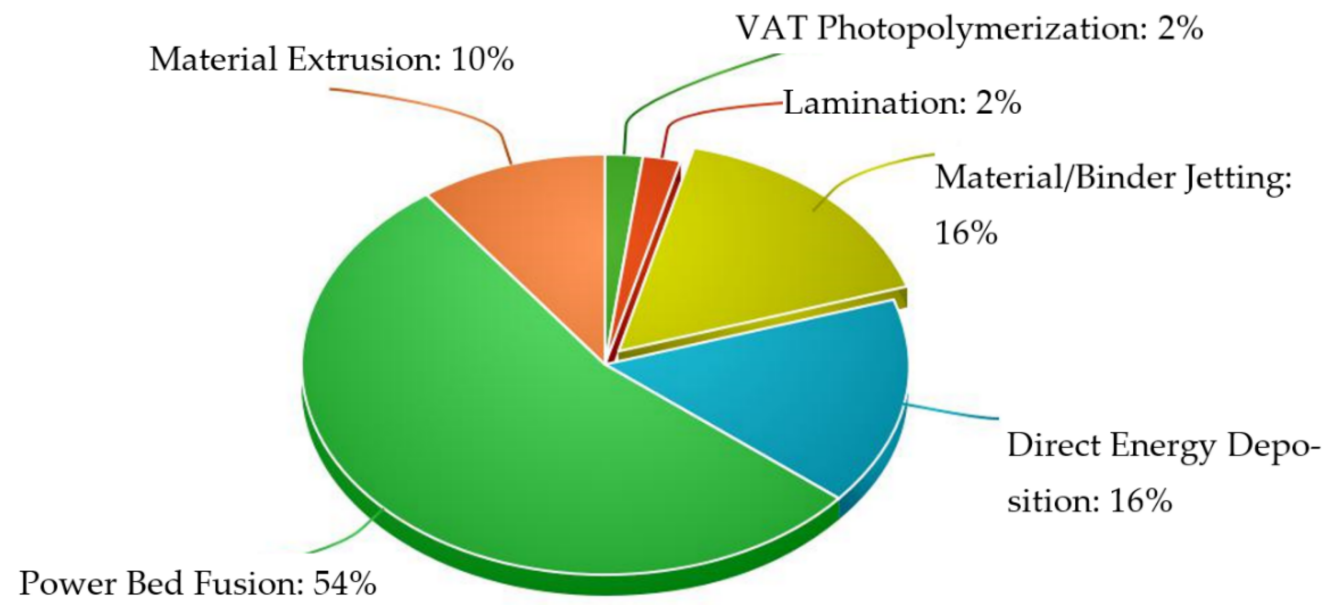

Figure 2. Metal Additive Manufacturing Market in 2020.

\subsection{Material Extrusion (ME)}

Figure 2 shows that ME technologies made up 10\% of the metal AM market in 2020 [18]. Stratasys Ltd. patented the Fused Deposition Modeling (FDM) process, which uses thermoplastic polymers, in 1989 [5]. In 2009, the patents expired, and other manufacturers started to build new versions of FDM, which are called Fused Filament Fabrication (FFF) [19]. One of the recent developments in the metal AM market is the development of metal filled filaments, which can be printed using FFF machines. In this filament, the metal powder is infused in a standard ABS or PLA filament, and the powder percentage can vary. The prints made using these filaments are not pure metal parts, but rather consist of metal particles in a polymer matrix, and are brittle and require care while handling the printed objects [20]. The parts fabricated using these processes are not metallic parts, but rather parts with metal content. It should be noted that the tensile strength of the filaments is reduced as the metal particle content increases; however, the thermal conductivity of the filaments increases, and can make them suitable for fabricating circuits and electromagnetic parts [21]. Bound Powder Extrusion (BPE) is another recent ME development in the metal AM market. In this technology, the filament consists of a plastic binding agent and fine metal powder that is extruded through a nozzle. The desired part is printed layer by layer in a fashion nearly identical to conventional FFF printing; however, this process is followed by two additional post processing operations: washing and sintering, to produce a final high density fully metal part. 


\subsection{Powder Bed Fusion (PBF)}

The majority of metal AM systems apply powder bed fusion (PBF) processes, and $54 \%$ of the metal AM market belongs to these processes as of 2020 (Figure 2). Common metal PBF processes are Direct Metal Laser Sintering (DMLS), Selective Laser Melting (SLM), Electron Beam Melting (EBM), and Direct Metal Laser Melting (DMLM). In general, there is not a great deal of difference in the versions of these laser technologies made by different companies. Moreover, there is little difference in the materials used between the different machines. This section describes the slight differences that exist between the different PBF technologies. Among these technologies, SLM and DMLS processes are exclusively used to produce metallic components [22]. In general, these two technologies use the same basic tenet. SLM, which is also called Laser Metal Fusion (LMF), is mainly used for single component metals such as Aluminium and DMLS is commonly used for metal alloys such as Aluminium and Titanium Alloys [23]. The DMLM process is very similar to the DMLS process, except that in the DMLM process, laser beams create ultra-thin metal layers and provides a homogenous melt pool [24]. Improved surface quality and lower levels of porosity are key advantages of this process over DMLS. In EBM technology, a high energy electron beam is used to fuse metal powder together, instead of a laser in SLM printers.

Table 1. AM Categories and Summary of the Common Metal AM Processes.

\begin{tabular}{|c|c|c|c|c|c|}
\hline AM Category & Metal AM Process & $\begin{array}{l}\text { Metal Printer } \\
\text { Manufacturer }\end{array}$ & Process Description & Pros/Cons & $\begin{array}{c}\text { Metallic } \\
\text { Material and } \\
\text { Manufacture }\end{array}$ \\
\hline $\begin{array}{l}\text { VAT Photopoly- } \\
\text { merization }\end{array}$ & $\begin{array}{l}\text { Digital Light Processing } \\
\text { (DLP) }\end{array}$ & $\begin{array}{c}\text { Asiga, DWS, Carbon, } \\
\text { Lithoz, Rapid Shape, } \\
\text { Kudo3D, FlashForge } \\
\text { MoonRay, Hunter, } \\
\text { CoLiDo, Monocure } \\
\text { 3D, Tethon 3D, } \\
\text { Prodways }\end{array}$ & $\begin{array}{l}\text { As shown in Figure 3a, VAT } \\
\text { Photopolymerisation } \\
\text { processes use a tank/vat of } \\
\text { liquid material, and a light } \\
\text { is used to cure the liquid } \\
\text { material and turn it into } \\
\text { solidified layers, the build } \\
\text { platform then moves away } \\
\text { from the liquid material } \\
\text { after each layer is solidified. } \\
\text { SLA is the oldest and most } \\
\text { common technology and } \\
\text { uses a UV laser to cure the } \\
\text { liquid material/resin [18]. } \\
\text { DLP technology cures the } \\
\text { resin by using a digital light } \\
\text { projector, and illuminates } \\
\text { images for each layer onto } \\
\text { the bottom of the resin } \\
\text { tank/vat [19]. } \\
\text { This group of AM processes } \\
\text { coveres just } 2 \% \text { of the metal } \\
\text { AM market in 2019 } \\
\text { (Figure } 2 \text { ). Two common } \\
\text { technologies in this category } \\
\text { that are used for printing } \\
\text { polumn of this table). The } \\
\text { partially metal components } \\
\text { are SLA and DLP [25]. It } \\
\text { should be highlighted that } \\
\text { parts produced using these } \\
\text { methods are not metallic } \\
\text { parts, but rather parts with } \\
\text { metal content. These two improve the } \\
\text { technologies enable } \\
\text { building metal containing } \\
\text { parts through the use of } \\
\text { composite resins that } \\
\text { include metallic particles } \\
\text { metile }\end{array}$ & $\begin{array}{l}\text { Pros: High level } \\
\text { of surface finish } \\
\text { and accuracy } \\
\text { (microns) } \\
\text { Cons: Slow } \\
\text { printing process } \\
\text { and post } \\
\text { processing } \\
\text { operations due to } \\
\text { the small surface } \\
\text { of the laser beam, } \\
\text { Relatively high } \\
\text { material cost, } \\
\text { Limited materials } \\
\text { to use. }\end{array}$ & $\begin{array}{c}\text { Composite resins } \\
\text { that include } \\
\text { metallic particles } \\
\text { such as tungsten } \\
\text { carbide (WC), } \\
\text { iron (Fe) or cobalt } \\
\text { (Co) and } \\
\text { Aluminium } \\
\text { (Al)-based } \\
\text { particles [27,28]. } \\
\text { Manufacturers: } \\
\text { Tethon3d, } \\
\text { ApplyLabWork. }\end{array}$ \\
\hline
\end{tabular}


Table 1. Cont.

\begin{tabular}{|c|c|c|c|c|c|}
\hline AM Category & Metal AM Process & $\begin{array}{l}\text { Metal Printer } \\
\text { Manufacturer }\end{array}$ & Process Description & Pros/Cons & $\begin{array}{c}\text { Metallic } \\
\text { Material and } \\
\text { Manufacture }\end{array}$ \\
\hline & & & $\begin{array}{c}\text { thermal and mechanical } \\
\text { properties of the 3D objects } \\
\text { printed using VAT } \\
\text { Photopolymerisation } \\
\text { technologies [26]. }\end{array}$ & & \\
\hline $\begin{array}{c}\text { Material } \\
\text { Extrusion (ME) }\end{array}$ & $\begin{array}{l}\text { Fused Deposition } \\
\text { Modeling (FDM) } \\
\\
\text { Bound Powder } \\
\text { Extrusion (BPE)—also } \\
\text { known as Atomic } \\
\text { Diffusion Additive } \\
\text { Manufacturing (ADAM) }\end{array}$ & $\begin{array}{c}\text { Stratasys, } \\
\text { Ultimaker, Aleph } \\
\text { Objects, 3Dgence, } \\
\text { XYZ Printing, } \\
\text { Desktop Metal, } \\
\text { Mark One, RepRap, } \\
\text { Zortrax, Raise3D, } \\
\text { Perfect Laser, } \\
\text { Builder 3D Printers, } \\
\text { RE:3D, Modix, } \\
\text { envisionTEC, } \\
\text { Xioneer systsems, } \\
\text { colorFabb } \\
\text { Desktop Metal, } \\
\text { Markforged, } \\
\text { Airwolf }\end{array}$ & $\begin{array}{l}\text { As shown in Figure } 3 \mathrm{~b}, \\
\text { melted material, which is } \\
\text { in the form of filament, is } \\
\text { selectively dispensed } \\
\text { through a heated extrusion } \\
\text { nozzle in a pre-determined } \\
\text { path to construct 3D parts } \\
\text { [29]. This process continues } \\
\text { layer by layer until the } \\
\text { desired part is printed. } \\
\text { In BPE technology, the } \\
\text { printing process is followed } \\
\text { by two post processing } \\
\text { operations: washing and } \\
\text { sintering, to produce a final } \\
\text { high density fully metal } \\
\text { part [30]. }\end{array}$ & $\begin{array}{l}\text { Pros: Relatively } \\
\text { slow process, } \\
\text { maintenance, and } \\
\text { material costs, } \\
\text { simplicity. } \\
\text { Cons: Difficult to } \\
\text { fabricate complex } \\
\text { parts, Low accuracy. }\end{array}$ & $\begin{array}{c}\text { Metal filled } \\
\text { filaments contain } \\
\text { very fine metal } \\
\text { powders such as } \\
\text { copper, } \\
\text { aluminium, and } \\
\text { stainless steel. } \\
\text { Manufacturers of } \\
\text { metal filled } \\
\text { filaments for } \\
\text { FDM printers: } \\
\text { ColorFabb, } \\
\text { Proto-pasta, } \\
\text { FormFutura, } \\
\text { Gizmo Dorks, } \\
\text { Amolen. }\end{array}$ \\
\hline $\begin{array}{l}\text { Powder Bed } \\
\text { Fusion (PBF) }\end{array}$ & $\begin{array}{l}\text { Selective Laser Melting } \\
\text { (SLM) } \\
\text { Electron Beam Melting } \\
\text { (EBM) } \\
\text { Direct Metal Laser } \\
\text { Melting (DMLM) }\end{array}$ & $\begin{array}{c}\text { 3D Systems, } \\
\text { Renishaw, SLM } \\
\text { Solutions, Concept } \\
\text { Laser (GE } \\
\text { Additive), EOS, } \\
\text { DMG Mori, } \\
\text { Precious } \\
\text { 3D Systems, SLM } \\
\text { Solutions, Xact } \\
\text { Metal, AddUp, } \\
\text { 3Dprotofab, Aurora } \\
\text { Labs, Raycham, } \\
\text { RAM3D } \\
\text { Arcam (GE } \\
\text { Additive), Jeol, } \\
\text { Freemelt } \\
\text { Concept laser, } \\
\text { Aurora Labs }\end{array}$ & $\begin{array}{l}\text { As shown in Figure } 3 c \text {, in } \\
\text { these processes thermal } \\
\text { energy such as electron and } \\
\text { laser beams selectively } \\
\text { melts and fuses areas of a } \\
\text { powder bed [31]. After } \\
\text { each print, the build plate is } \\
\text { lowered, and a roller adds } \\
\text { a new layer of powdered } \\
\text { materials and sinters it to } \\
\text { the previous layer. }\end{array}$ & $\begin{array}{l}\text { Pros: No support } \\
\text { structure required, } \\
\text { Prints complex } \\
\text { geometries, No } \\
\text { post-processing } \\
\text { operations required } \\
\text { for support } \\
\text { structure removal, } \\
\text { Wide range of } \\
\text { materials. } \\
\text { Cons: Relatively } \\
\text { expensive and } \\
\text { complex, Size } \\
\text { limitation, } \\
\text { Considerable level } \\
\text { of distortions, } \\
\text { Surface finish } \\
\text { depends on powder } \\
\text { grain size. }\end{array}$ & $\begin{array}{c}\text { Metallic powders: } \\
\text { Stainless Steel, } \\
\text { Nickel, Titanium } \\
\text { Alloys, and } \\
\text { Aluminium } \\
\text { Alloys, Bronze, } \\
\text { Cobalt } \\
\text { Chromium, Tool } \\
\text { Steel, Super } \\
\text { Alloys, and } \\
\text { metal-ceramic } \\
\text { composites. }\end{array}$ \\
\hline $\begin{array}{l}\text { Directed Energy } \\
\text { Deposition } \\
\text { (DED) }\end{array}$ & $\begin{array}{c}\text { LMD } \\
\text { Wire-based } \\
\text { Joule printing } \\
\text { LENS } \\
\text { LC }\end{array}$ & $\begin{array}{l}\text { Additec, Formalloy, } \\
\text { InssTek } \\
\text { Digital Alloys } \\
\text { Optomec } \\
\text { Laser Cladding } \\
\text { Technologies, } \\
\text { Laserline, Preconic } \\
\text { Ambit Technology, } \\
\text { Mazak, ELB }\end{array}$ & $\begin{array}{l}\text { A nozzle combined with a } \\
\text { multi-axis robot that } \\
\text { selectively adds material to } \\
\text { a substrate with sufficient } \\
\text { energy to create a layer. } \\
\text { Material comes either in } \\
\text { the form of metal wire or } \\
\text { powder. Figure 3d,e } \\
\text { present a typical schematic } \\
\text { of two thermal energy DED } \\
\text { processes. }\end{array}$ & $\begin{array}{c}\text { Pros: Cold spray } \\
\text { systems-Superior } \\
\text { mechanical } \\
\text { properties, No } \\
\text { phase change, High } \\
\text { deposition rate, Low } \\
\text { oxidation, Large } \\
\text { fabrication size, and } \\
\text { High speed } \\
\text { production [32,33]. } \\
\text { Thermal energy } \\
\text { systems- } \\
\text { Unconstrained build } \\
\text { volume, High } \\
\text { deposition rate, Cost } \\
\text { effective for large } \\
\text { and medium } \\
\text { complexity metallic } \\
\text { products [34], Used } \\
\text { for damaged } \\
\text { components. } \\
\text { Cons: Environmental } \\
\text { impacts, Post }\end{array}$ & $\begin{array}{c} \\
\text { Powders- } \\
\text { Titanium Alloys, } \\
\text { Stainless Steels, } \\
\text { Nickel Alloys, } \\
\text { Cobalt Alloys. } \\
\text { Wires-Titanium } \\
\text { and Titanium } \\
\text { Alloys, Inconel } \\
\text { 600, 625, and 718, } \\
\text { Nickel-based } \\
\text { alloys, Copper, } \\
\text { Nickel Alloys, } \\
\text { Stainless Steels } \\
\text { 300 series, } \\
\text { Aluminium } \\
\text { Alloys, Alloy } \\
\text { Steels and } \\
\text { Magnesium alloy } \\
\text { [35]. }\end{array}$ \\
\hline
\end{tabular}


Table 1. Cont.

\begin{tabular}{|c|c|c|c|c|c|}
\hline AM Category & $\begin{array}{l}\text { Metal AM } \\
\text { Process }\end{array}$ & $\begin{array}{l}\text { Metal Printer } \\
\text { Manufacturer }\end{array}$ & Process Description & Pros/Cons & $\begin{array}{c}\text { Metallic } \\
\text { Material and } \\
\text { Manufacture }\end{array}$ \\
\hline & & & & $\begin{array}{l}\text { processing may be } \\
\text { required, Limited } \\
\text { materials due to } \\
\text { metallurgical } \\
\text { properties. }\end{array}$ & \\
\hline $\begin{array}{l}\text { Material Jetting } \\
\text { (MJ) }\end{array}$ & $\begin{array}{l}\text { NanoParticle } \\
\text { Jetting (NPJ) }\end{array}$ & XJet & $\begin{array}{l}\text { As shown in Figure } 3 \mathrm{f} \text {, the } \\
\text { photopolymer resin is selectively } \\
\text { sprayed to the target location in } \\
\text { droplets, and UV light is used to } \\
\text { cure and solidify the liquid } \\
\text { material. Once a layer is printed, } \\
\text { the build platform moves down, } \\
\text { and MJ prints a new layer upon } \\
\text { the previous layer until the part is } \\
\text { completely built. }\end{array}$ & $\begin{array}{l}\text { Pros: High level of } \\
\text { surface finish and } \\
\text { accuracy (microns), } \\
\text { Prints complex } \\
\text { geometries, } \\
\text { Simplicity, Prints } \\
\text { multiple colours } \\
\text { with several } \\
\text { materials in a single } \\
\text { print [36], } \\
\text { High-density metal } \\
\text { parts, Easy removal } \\
\text { of support } \\
\text { structures. } \\
\text { Cons: Limited size, } \\
\text { Limited materials } \\
\text { to use }\end{array}$ & $\begin{array}{c}\text { Liquid material } \\
\text { infused with } \\
\text { metal } \\
\text { nanoparticles. }\end{array}$ \\
\hline
\end{tabular}

As shown in Figure 3g, a liquid-state binder agent is selectively deposited through a print head onto the powder bed, to bind the powder and form a layer of a part [37]. The binder consolidates the powdered materials within and between sliced layers at room temperature [38]. Once a layer is printed, the build plate moves down, and the powder roller spreads a new layer of powdered material. This process continues until the desired object is completely printed, then this part can be used as it is, cured, or sintered [38]. Once a layer is printed, the build plate moves down, and the powder roller spreads a new layer of powdered material. This process continues until the desired object is completely printed, then this part can be used as it is, cured, or sintered [38].
As shown in Figure 3h, sheets of materials are bonded layer by layer to build the desired component. The sheet of the material is supplied from a feed roller. Each sheet is cut to shape with a cutting tool, such as a laser to fit to the part's cross-section.

After each layer, the build platform moves down, and the new layer of material is fed. SL covers just $2 \%$ of the metal AM market in 2019. LOM technology is primarily used for paper; however, it may use metal sheet materials, and parts printed with LOM are often used for visual models, and are not recommended for structural use [4]. The most
Pros: Relatively quick and clean, Low capital

investment, Low distortions such as curling and warping.

Cons: Relatively weak material properties.
Stainless steel, Inconel, Cobalt-chromium (Co-Cr) alloy, Copper.
Pros: High speed, Relatively low cost.

Cons: Limited materials, Printed limited Geometries.
Aluminium, Copper, Stainless Steel, Titanium, Metal matrix composites. 
Table 1. Cont.

\begin{tabular}{|c|c|c|c|c|c|}
\hline AM Category & Metal AM Process & $\begin{array}{l}\text { Metal Printer } \\
\text { Manufacturer }\end{array}$ & Process Description & Pros/Cons & $\begin{array}{c}\text { Metallic } \\
\text { Material and } \\
\text { Manufacture }\end{array}$ \\
\hline & & & $\begin{array}{l}\text { commonly used metal SL } \\
\text { technique is UAM, also } \\
\text { referred to as ultrasonic } \\
\text { consolidation (UC), which } \\
\text { was first developed by } \\
\text { White [39]. This process } \\
\text { bounds metallic sheets } \\
\text { together using an ultrasonic } \\
\text { welding operation [40]. In } \\
\text { this process, an additional } \\
\text { machining operation, which } \\
\text { is controlled by Computer } \\
\text { Numerical Control (CNC), } \\
\text { is required to remove the } \\
\text { unbounded material [40]. }\end{array}$ & & \\
\hline
\end{tabular}

This process may also be known as Selective Electron Beam Melting (SEBM) or Electron Beam Additive Manufacturing (EBAM) [44]. EBM technology leads to higher productivity relative to SLM systems because parts can be stacked within the build volume, however higher levels of distortion and residual stresses remain inside the AM parts due to the high energy density and rapid thermal cycles [45].

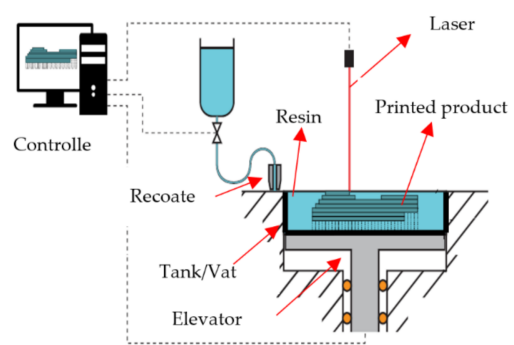

(a)

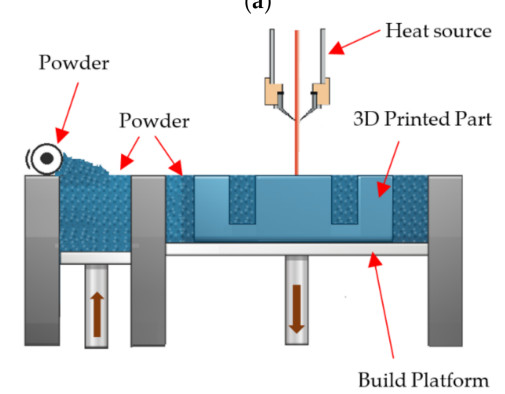

(c)

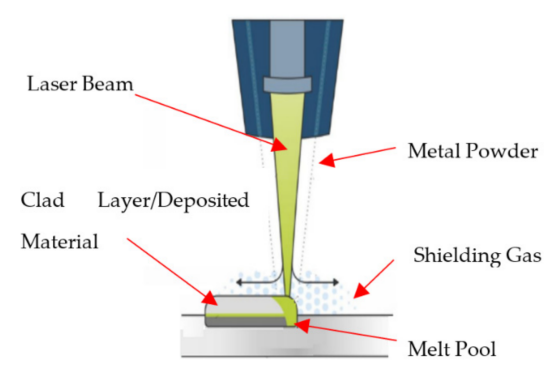

(e)

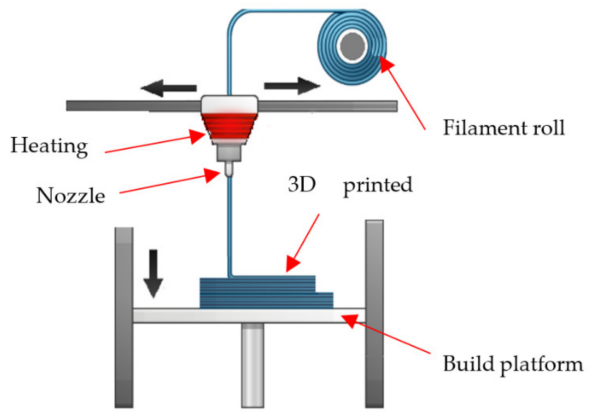

(b)

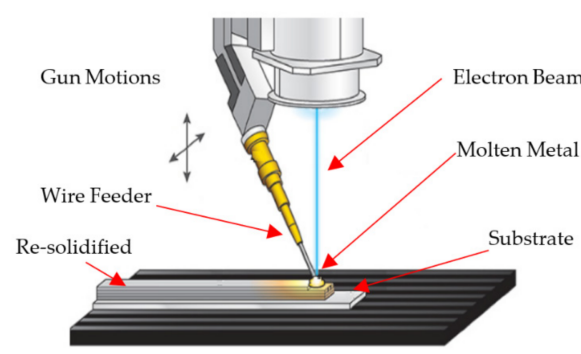

(d)

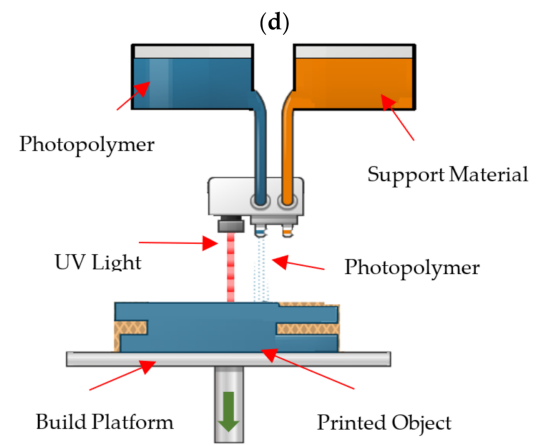

(f)

Figure 3. Cont. 


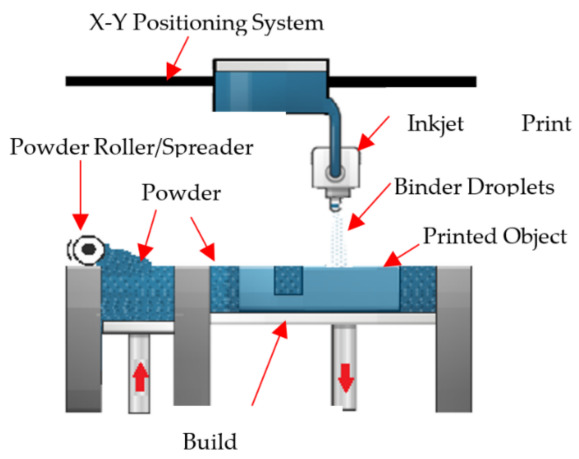

(g)

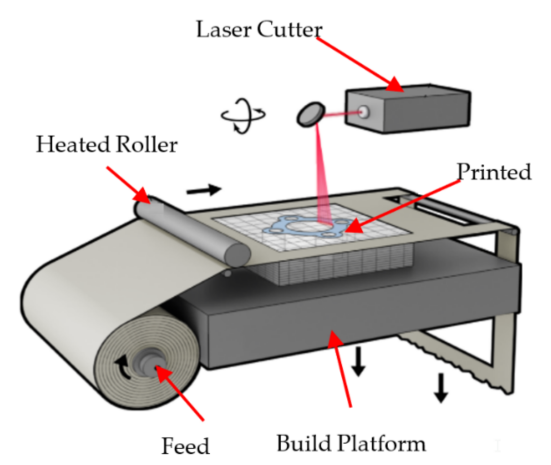

(h)

Figure 3. Metal AM Processes; (a) VAT Photopolymerisation System [41], (b) Material Extrusion Process, (c) Power Bed Fusion Process, (d) Wire DED Process [40], (e) Powder DED Process [42], (f) Material Jetting Process, (g) Binder Jetting Process, and (h) Sheet Lamination Process [43].

\subsection{Directed Energy Deposition (DED)}

DED covers $16 \%$ of the metal AM market (as shown in Figure 2), and can be grouped into two main categories from an energy perspective: cold spray and thermal energy [46]. Cold spray, also known as kinetic energy, adds material in the form of fine particles to a substrate with sufficient kinetic energy to create a dense coating or layer [47]. The other group of DED systems focuses on thermal energy, through the use of a laser beam, an electron beam, plasma, or arc. This group selectively melts the feedstock material, which is either wire or powder, and successively add it onto the build platform [46]. DED technologies are primarily used for fabricating metal components [48]. This AM group applies robotic welding processes for printing at higher deposition rates, but with lower resolution [34]. Table 1 shows common DED processes: Electron Beam Additive Manufacturing (EBEAM), Wire and Arc Additive Manufacturing (WAAM), Wire-based Joule printing, Laser-Engineered Net Shaping (LENS), Lase Clading (LC), and Hybrid Systems (HS). In EBEAM, which is also called EBAM, the energy source and the material are an electron beam and in wire form, respectively (Figure 3d) [49]. WAAM technology is a wire-based DED process approach where the wire feedstock is melted through an electrical arc as an energy source, and the melted material is deposited layer upon [35]. Three common welding technologies that might be employed in WAAM systems are Gas Metal Arc Welding (GMAW), Gas Tungsten Arc Welding (GTAW) or Plasma Arc Welding (PAW) [35]. For instance, Rapid Plasma Deposition (RPD) is a WAAM system that uses a plasma arc to melt Titanium Alloy wire in an inert, argon gas environment [5].

Another technology is the Joule Printing system, which has been supported by Boeing, Lincoln Electric, Khosla Ventures and G20 Ventures [50]. In this technology, electrical current passes through the wire feedstock to melt and fuse it to the previous layer to fully bond layers. Since no arc is created, and positioning and melting the raw material is performed in one step, the Joule printing process is a simple and rapid process. Furthermore, any metallic material in wire form can be printed by this technology [50]. Figure 3e shows another DED technology in which the substrate is melted and metal powder is placed on the surface of the molten substrate. This technology is called Blown Powder Technology (BPT) [51]. Unlike other powder AM processes, these technologies are not on the basis of a powder bed, but the powder and the laser beam are focused on to the substrate to deposit the metallic material. Indeed, the metal powder is entered into a pool of molten metal, and the heat source is a focused laser beam enabling manufacture of near net shape parts with high precision [52]. In addition, an inert shroud gas is used to cover molten metal and powders from oxygen. This technology is mainly used to produce coatings with defined properties for repairing worn or damaged components as well as to add features on a part surface [53]. LENS is one of the BPT technologies where a focused, high powered laser beam is used to melt metallic powder [52]. This technology was created at Stanford 
University and US Sandia National Laboratories, and commercialised by Optomec [54]. Since then, the same technology has also been manufactured by POM group under the name Direct Metal Deposition (DMD) [5]. In the LENS process, the metal powder is applied only where powder is being added to the substrate at that moment.

In addition to the above, the BPT includes various techniques such as Laser Metal Deposition (LMD), Laser Solid Forming (LSF), Direct Laser Metal Deposition (DLMD), Direct Laser Deposition (DLD), Direct Light Fabrication (DLF), Laser Deposition Welding (LDW), Powder Fusion Welding (PFW), Directed Light Fabrication (DLF), Electron Beam Direct Manufacturing (EBDM), and Direct Metal Tooling (DMT) depending on the application or specifications of the method [55-58]. Among these technologies, LMD has received attention from researchers and industries in the last few years [59]. In this process, a metallic powder, which is carried by an inert gas, is melted using a high-power laser beam. Within this process, the material is sprayed through a nozzle that has a coaxial laser beam passing through it [60]. This process has been used for manufacturing high precision near net shape products and repairing high complex shapes [61]. This is due to the fact that the resulting heat affected zone of this process is small, which results in low distortion.

LC is another process of the DED process is in which a laser heat source is applied to deposit a thin layer of preplaced materials on a substrate, which is moved using a controlled system [62]. According to Toyserkani et al. [63], LC uses the following feeding methods: a one-step process that includes paste feeding, powered injection and wire feeding, and a two-step process, which is called replaced powder. During the one-step process, the cladding materials are deposited into the substrate and a shallow molten pool is created concurrently; whereas during the two-step process, the cladding material, which is in the form of powder, is deposited on the substrate's surface and then the Laster beam is irradiated [64]. The LC technology has the capability to be attached to a 5-axis robotic arm [65]. This gives the opportunity to add metal coats onto curved surfaces, and to repair damaged parts, particularly for the aerospace applications (see Section 2.2). Another thermal-based DED process technology is hybrid system (HS), wherein a DED process is combined with subtractive processes such as milling in a single machine to provide tighter tolerances and multi-tasking capabilities [66].

\subsection{Material Jetting (MJ)}

Figure 2 shows that material jetting (MJ) and binder jetting (BJ) processes make up $16 \%$ of the metal AM market in 2020. The primary differences between these two processes are discussed in Table 1. As shown in Figure 3f, MJ technology uses photopolymers as the material and applies a UV light to selectively cure the printed layer. As indicated in Table 1, Nano Particle Jetting (NPJ) is one of the MJ technologies that enables the production of metal parts through the use of composite resins that are infused with metallic nanoparticles such as stainless steel.

\subsection{Binder Jetting (BJ)}

As presented in Figure 3g, BJ technology uses metal powder alongside a liquid-state binder to print the desired metal parts in layers. In this process, the binder droplets consolidate the powdered materials within and between sliced layers [38]. The BJ technology requires no support structures and prints much more accurate objects compared to metal powder bed fusion. Table 1 provides further information on this technology.

\section{Industrial Applications}

Metal AM opens up new opportunities to improve manufacturing capability. Short lead times, access to new materials, material waste reduction, and fabrication of novel complex geometries and difficult to machine materials are key factors to encourage industry sectors to adopt metal AM technologies [67]. This section presents a range of recent applications in different industries along with several case studies where AM technologies have been successfully applied. 


\subsection{Automotive}

One of the leading industries in the AM market is the automotive industry, with AM average growth of $3.6 \%$ in the recent years [5]. The advances in metal AM have provided opportunities for more flexible, optimized, and robust designs; lighter, stronger, and safer products; faster customisation, and reduced lead times and costs. Therefore, different automotive companies are beginning to use metal AM. For instance, Figure 4a shows a 3D printed steering knuckle, also known as an upright. The Formula Student Germany 2012 used EOS DMLS technology to manufacture a light-weighted upright, and the weight of this component was reduced by $35 \%$ compared with the existing cast part [68].

German-based based automotive company, the BMW Group, is a long-standing partner of HP and EOS and uses a variety of AM technologies from these two companies [69]. For instance, BMW fabricated a window guide rail in the i8 Roadster using the HP Multi Jet Fusion metal 3D printer. This AM technology is being used in production to manufacture 100 rails in $24 \mathrm{~h}$ [70]. In addition, the i8 Roadster includes another 3D printed component; a fixture for the soft-top attachment, which is made from an aluminium alloy. This component is $44 \%$ lighter than the injection-moulded plastic attachment that was originally applied, but is ten times stiffer [69]. BMW is also rolling out an innovative engine, which is a replacement for their S55 engine. This engine consolidates several components, including a cylinder head manufactured using a PBF metal AM printer [71].

Bugatti, a French car manufacturer, has revealed a range of metal AM components. Figure $4 \mathrm{~b}$ shows a Bugatti $2.9 \mathrm{~kg}$ Ti6Al4V brake caliper which was produced in 2018 for future car models. This caliper is one of the largest calipers in the world, and is made using an SLM Solutions SLM 500 multi-laser printer, taking $45 \mathrm{~h}$ to print with 2213 layers [72,73]. According to Bugatti, this caliper has a tensile strength of $1225 \mathrm{MPa}$. The size of this caliper is $410 \times 210 \times 136 \mathrm{~mm}$ with a wall dimension that ranges from 1 to $4 \mathrm{~mm}$ thick. It is noteworthy that the bracket of the caliper is $40 \%$ lighter than the original Aluminium bracket, which weighed approximately $4.9 \mathrm{~kg}$ [72]. Clearly, this weight saving comes from Titanium's superior stiffness-to-weight and strength-to-weight ratios compared with aluminium. Figure $4 \mathrm{c}$ shows the topology optimised bracket with integrated water cooling circuits, which was developed for Bugatti Chiron and has been used in all series of their cars since its launch [72]. This metal AM product is made of AlSi10Mg on an SLM 280, manufactured by SLM Solutions. The design of this Bugatti component helps to keep the brake disc temperature at an acceptable level, even under the most extreme weather and operating conditions. Audi, a German automobile manufacturer, is collaborating with SLM Solution Group for producing customised products, spare parts, and parts that are requested rarely [67,68]. For instance, a water adapter for the Audi W12 engine has been manufactured additively.

The Honda Motor company, a Japanese automobile manufacturer, is also using metal AM technologies to manufacture the body shell parts of its configurable electric car [5]. German Airbus subsidiary APWorks is using metal AM technologies to fabricate lightweight structures in Scalmalloy, which is an alloy made from Scandium, Aluminium, and Magnesium. Figure $4 \mathrm{~d}$ shows an AM hollow motorbike chassis structure, which is $30 \%$ lighter than the original version using standard materials and manufacturing [74]. Scalmalloy is highly recommended for high-performance applications, and it is strong, corrosion resistant, and light weight with high ductility [75].

\subsection{Aerospace}

One of the earliest adopters of AM technologies is the aerospace industry. All sectors of this industry such as commercial aircraft, military applications, and missile systems are applying AM technologies [10]. The capability of metal AM to perform rapid tooling and repairing, fabricate freeform and complex geometries, and consolidate parts, makes it ideal for the aerospace applications [76]. Moreover, the aerospace components are commonly made of difficult to machine materials such as high resistant super-alloys [77]. 


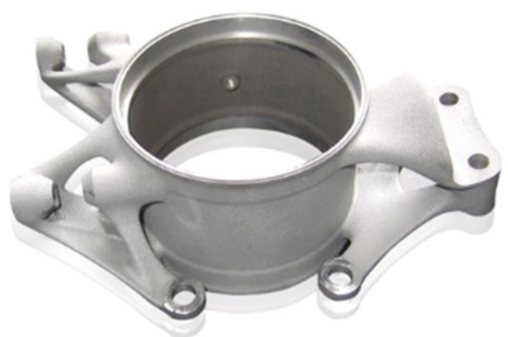

(a)

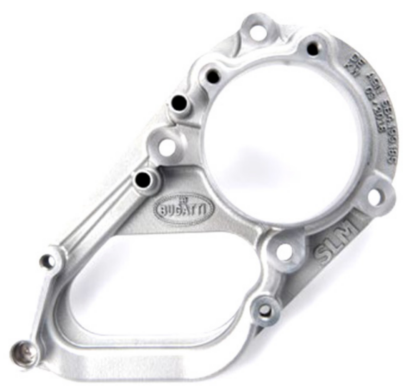

(c)

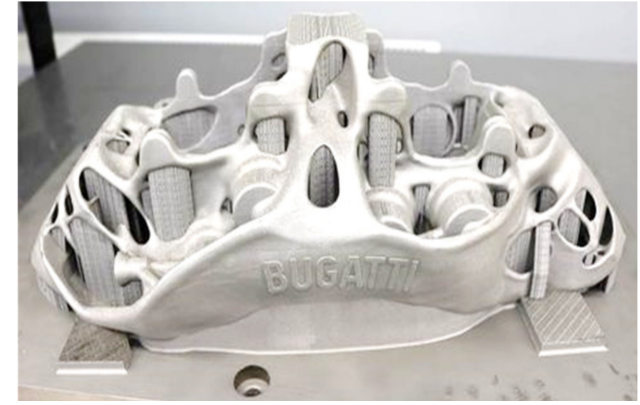

(b)

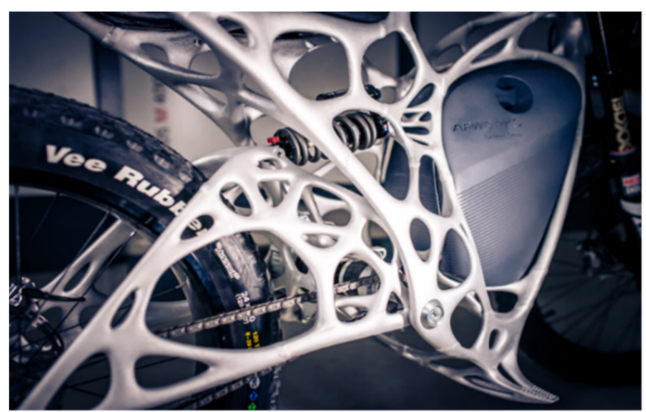

(d)

Figure 4. Automotive additive manufactured components: (a) Steering knuckle [68], (b) Bugatti brake caliper [72], (c) Bugatti topology optimised bracket [72], and (d) Lightweight structure made in Scalmalloy aluminum [74].

General Electric (GE) Aviation uses Concept Laser and Arcam metal printers to manufacture fuel nozzles for its new LEAP engine [10,78]. Figure 5a shows the LEAP fuel nozzle, which is $25 \%$ lighter and stronger than the original nozzle. More importantly, this component boosts the fuel efficiency of the engine up to $15 \%$ higher than the previous best CFM56 engines [77]. Figure $5 b$ shows another additive manufactured product, the GE Turboprop engine, which features subassemblies with just 12 parts, in stark comparison to the original engine that had 855 parts. Chapin reported that the novel AM Turboprop also boosts the fuel burn efficiency by up to $20 \%$.

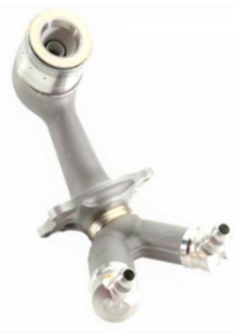

(a)

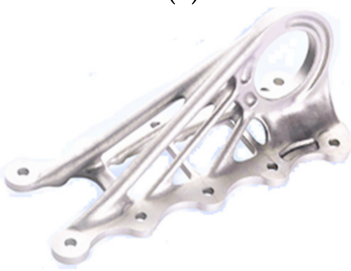

(c)

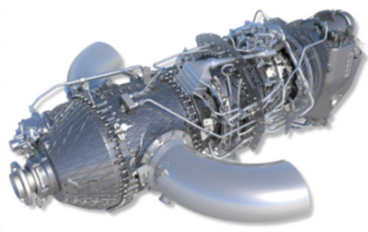

(b)

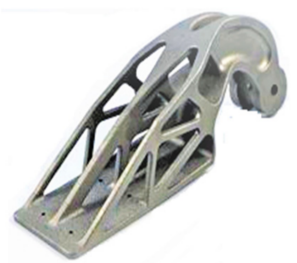

(d)

Figure 5. Aerospace additive manufactured components [77]: (a) GE Leap Nozzle, (b) GE Turboprop Engine, (c) Airbus A350 XWB jet wing bracket, and (d) Titanium door hinge. 
Furthermore, Airbus is using EOS and Concept Laser machines to manufacture metal brackets and bleed pipes for its aircrafts. Moreover, this company is producing large-scale AM airframe components in collaboration with Arconic [10]. Figure 5c shows an AM wing bracket that is printed with a Concept Laser machine, for the next generation Airbus A350 XWB jets [77]. Figure 5d shows an AM lightweight Titanium Ti64 turbine cover door hinge, used on an Airbus A380, printed with an EOS laser sintering machine. Another step of this company toward use of metal AM is the development of optimised A320 components and redesigning Titanium parts of the A350 [5].

In addition to the above, DED technologies have received considerable attention from the aerospace industry in recent years. For instance, LMD technology was used for fabricating the impeller blades of turbomachinery as well as repairing damaged areas [79]. This metal AM process provides 'Near-Net-Shape' geometry [80]. DED technologies are also used for the repair of turbine airfoils, engine combustion chambers, and blisks [10]. In another research study, Wilson et al. [81] applied LENS technology to repair defective voids in turbine airfoils. The results showed that the repaired airfoil matched the geometry of the original geometry with the $0.03 \mathrm{~mm}$ mean accuracy, improved the carbon footprint by $45 \%$ and increased the total energy saving by up to $36 \%$.

From the above, it can be seen that the aerospace industry has already started to receive benefits from adoption of AM technologies. According to a report published by Raja et al. [82], the aerospace industry benefits from AM technologies in different ways as follow: Lead time is shortened by up to $70 \%$; Non-recurring costs is reduced by up to $45 \%$; and mass is decreased by $35 \%$ or more.

\subsection{Medical and Dental}

The medical and dental industries are well-suited to the application of metal AM technologies for making end-use products. Metal AM technologies enable these industries to fabricate custom models tailored to patient needs and access to new materials. For instance, LimaCorporate company based in Italy has been developing Titanium-alloy orthopedic devices with Metal PBF and Arcam's EBM technologies [5]. Figure 6a shows a commercially available metal AM orthopedic device. Another example is the Titanium AM spinal cage produced by Nexxt Spine based in USA (Figure 6b). According to this company, spinal surgery is becoming more commonplace due to ageing, spinal tumors or trauma [83]. Therefore, Nexxt Spine is developing additively manufactured porous Titanium spinal implants. Another example is custom orthopedic implants based on the accurate capture of bony structures. Harrysson et al. [84] developed integrated implants based on a CT scan and fabricated the custom implants, which were made of Ti6Al4V, via the EBM or DMLS technologies. Some companies that have used AM technologies to manufacture dental/medical devices are Osseus Fusion Systems, OMX Solutions, Egan Dental Laboratory, Johnson \& Johnson Medical Devices, and Endocon GmbH.

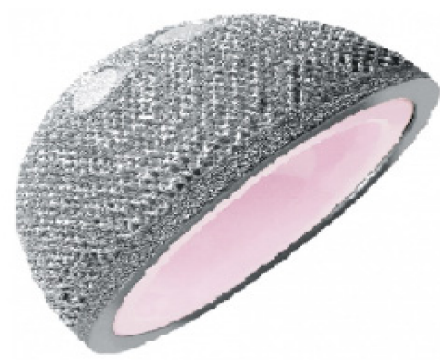

(a)

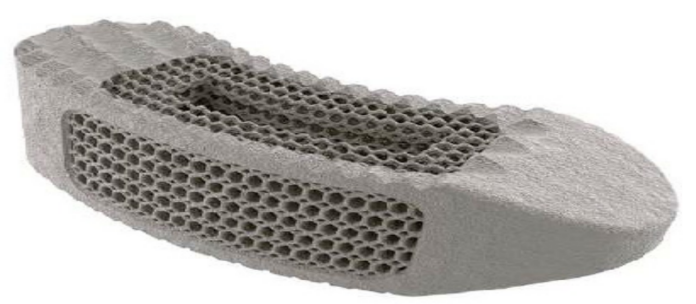

(b)

Figure 6. Dental and Medical additive manufactured components: (a) titanium-alloy orthopedic device [4], and (b) porous titanium spinal implant [83]. 
In addition to the above applications, researchers investigated the applications of metal AM in the medical industry. For instance, Vilardell et al. [85] developed topology optimised human using lattice structures. The novel geometries were made of Ti6Al4V and printed by a SLM EOS M28 printer. The results showed that the new designs can reduce the stress shielding effect on implant applications. In another study, a PBF printer made by Aurora Labs was applied to fabricate a dental strut-like geometry [86]. The results showed that material properties of the new product provide a low hardness near the gums. Revilla-León et al. [87] reviewed several recent medical and dental AM applications for interested readers.

\subsection{Building and Construction}

The scale of use of metal AM technologies for construction applications is currently low due to long printing times, small print volumes, high initial cost, and environmental issues; however, the number of applications in this field is increasing. For instance, Arup Group, an international engineering consultancy, developed a topology optimised node (Figure $7 \mathrm{a}, \mathrm{b}$ ). This component is made of stainless steel and it is $75 \%$ lighter than the original node, which is manufactured by traditional methods [88]. Figure 7c shows the printed Nematox facade node, which is developed at the University of Applied Sciences in Detmould. This part is made of Aluminum and it is printed with the Concept Laser system [89]. Another example of metal AM application is the MX3D bridge (Figure 7d). The Joris Laarman Lab and Arup use a WAAM system, which is attached to a robotic arm to print stainless steel components of the Amsterdam's bridge [9].

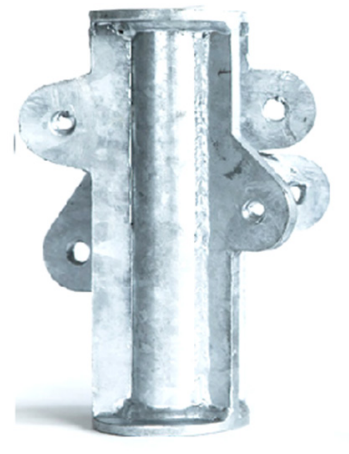

(a)

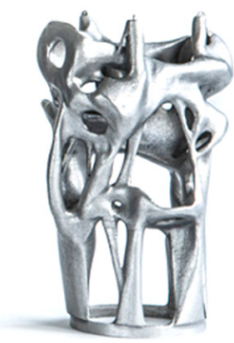

(b)

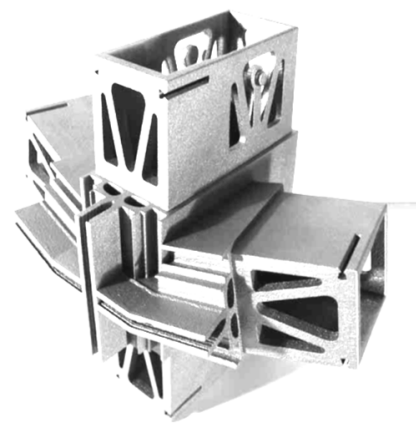

(c)

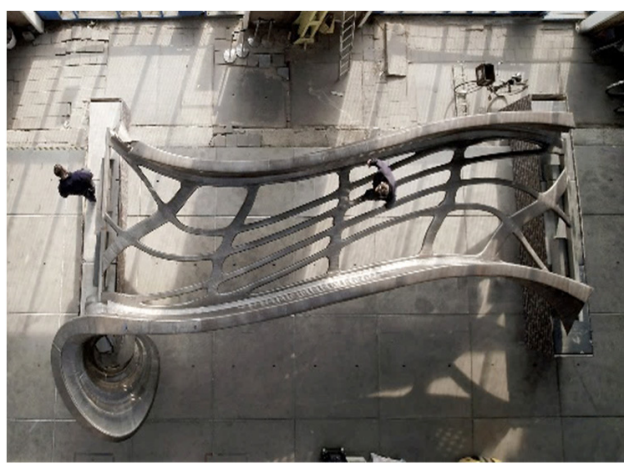

(d)

Figure 7. Building components [88]: (a) Arup original node, (b) Arup topology optimized node, (c) Nematox facade node, and (d) Max 3D bridge [9].

The above literature shows that metal AM is enabling the construction industry to create complex structural shapes with minimised weight and a reduced production lead time. Currently, metal AM is used for production of customized components on demand. Furthermore, metal AM is beneficial for the circumstances where construction components are lost or damaged, and on-site production using AM can be of significant benefit as waiting for replacements may cause construction delays and costs [88].

\subsection{Electronics and Communication}

Over the past years, metal AM has received attention from researchers and industries to make significant inroads in the design and fabrication of novel electronic and communication components such as resistors, circuit boards, antennas, waveguides, and couplers [90-93]. These electronic and communication parts are made of functional materials such as metal, semi-conductor, and polymer using printing and/or patterning technologies. Among these materials, metal/inorganics are commonly used in this industry sector as they offer good conductivity and durability [90,93]. For example, antennas that are made of conductive materials, such as ferrite, are essential components in wireless 
communications [94]. These products require smaller structures to provide a high level of carrier frequency of antennas [92]. Many researchers have explored AM techniques to develop uniquely shaped antennas. For instance, Goh et al. [95] employed a Fujifilm Dimatix DMP-2800 inkjet printer to fabricate patch antennas for low-power wireless applications.

The cartridge includes $1.5 \mathrm{~mL}$ of ink with silver nanowires. The Robert Hofmann company developed a lightweight RF filter for communication satellites [5]. Figure 8 shows an AM RF antenna manufactured by Optisys LLC. This company manufactured a metallic micro-antenna with Concept Laser's PBF technology, and this AM product is employed in aerospace and defence applications. Compared to an equivalent conventionally manufactured antenna, the AM antenna provides benefits such as $95 \%$ weight saving, $20 \%$ production cost reduction, and lead time reduction from eleven months to two months [96]. Another example of the metal AM application is developing high efficiency metal waveguides. Verploegh et al. [97] developed a W-band component, which includes a $10 \mathrm{~cm}$ straight waveguide piece and a $20 \mathrm{~dB}$ coupler. This component was manufactured with DMLS technologies in Maraging Steel (MS), which provides structural integrity and reasonable conductivity.

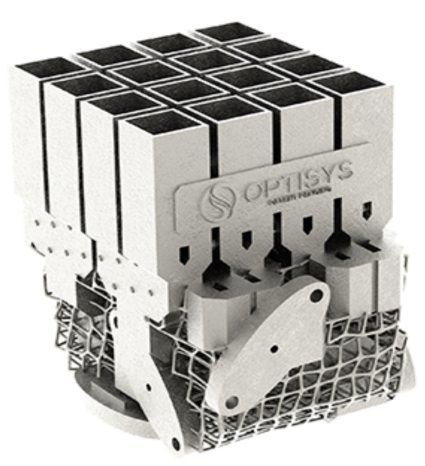

Figure 8. Lightweight AM antenna [96].

\subsection{Oil and Gas}

The world economic forum has estimated that AM could eventually save costs of approximately AU $\$ 44$ billion (US $\$ 30$ billion) in the oil and gas industry [98]. This is a significant potential in the application of AM technologies across the upstream and midstream oil and gas value chain. Another benefit of metal AM in the Oil and Gas industry is reducing lead times and consequently improving the supply chain efficiency [99]. However, this industry has been slow in embracing metal AM for manufacturing enduse products [100], there are some successful applications. For example, the AM gateway manifold of Titanium for pipelines was designed by Safer Plug Company (SPC) and printed by the AM production company 3T RPD using a PBF system. Lloyd's [101] claims that the production of this part with conventional manufacturing systems is nearly impossible due to complex internal channels. Today, GE uses the ability of metal AM techniques to manufacture control valve parts with complex shapes and configurations such as hollow structures, curved shapes, meshes, etc. for use across different applications in the energy sector [102].

Siemens is producing a number of metal AM products for the oil and gas industry such as nickel alloy gas turbine blades, fuel nozzles, gas turbine burners, heat shields impellers, and swirlers. One of the successful examples of metal AM application at Siemens is the production of an advanced burner swirl for the SGT-750 gas turbine. For this component, metal AM enabled manufacturing of a swirl shape. Another effective application of metal AM technology is manufacturing a water pump impeller of the fire protection system at Slovenia power station [98]. Siemens also designed metal additively manufactured sealing rings of SST-300 steam turbines, which were used in India in 2018. Figure 9 shows some of these examples [103]. 


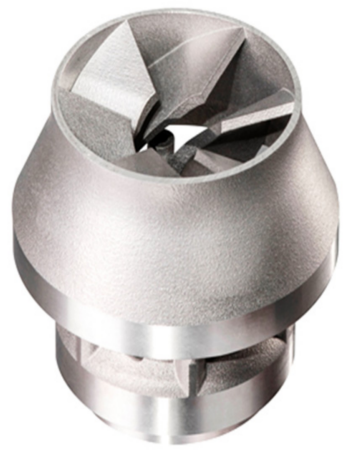

(a)

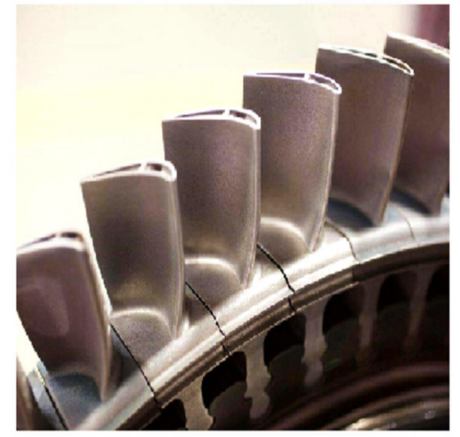

(b)

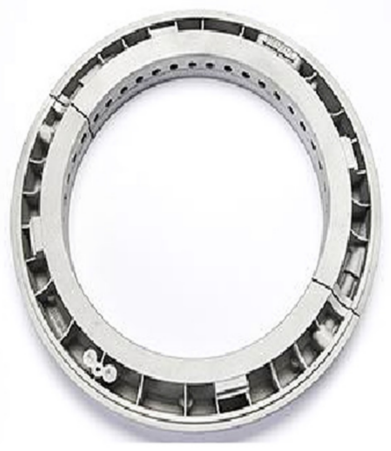

(c)

Figure 9. Siemens Oil and Gas AM components [103]: (a) burner head, (b) turbine blade, and (c) sealing ring.

It can be seen that the oil and gas industry continues to drive the industrialisation of metal AM products. Barnes and Camisa [102] believed that AM also has the potential to manufacture lightweight offshore facilities such as separators, pumps, and deck structures through topology optimisation and use of lattice/cellular structures. It should be highlighted that application of metal AM in the oil and gas industry requires feasibility analysis, strategic planning, and careful examination to avoid excess costs and enjoy AM benefits such as lead-time reduction, enhanced design complexity, improved functionality, and increased supply chain efficiency.

\subsection{Mining}

Mining projects are often operated in remote and high-risk locations. Thus, when equipment components fail, supply chains are compromised due to access limitation, downtime, and delays in production due to lead-times in obtaining replacement parts. In such circumstances, metal AM may be very suitable, particularly for the manufacturing of on-demand spare parts [104]. The literature review shows that the mining industry has been slow in adopting metal AM technologies. However, some research projects are exploring applications relating to the production of mining components. For example, Aurora Labs, an Australian metal 3D printer manufacturer, has collaborated with Fortescue Metals Group (FMG), an Australian mining company, to develop on-demand replacement parts for remote mining projects. Through rapid replacement of components, the mining sector can realise up to a $50 \%$ downtime cost reduction [105]. Sandvik, a Swedish equipment and tool manufacturer, is also working on a metal AM project. This company has invested approximately AU \$30 million (US \$25 million) to promote the use of Metal AM in the mining sector [106].

The goal of this project is applying fine metal powders in the production of mining components such as mining gears. In addition, there is a joint project towards adoption of metal AM supported by the IMCRC (Innovative Manufacturing Cooperative Research Center), involving a partnership between Downer's Mineral Technologies and the University of Technology Sydney Rapido center. The aim of this project is to research solutions that will advance methods of production of mineral separation equipment [107]. It can be seen that that AM has the potential to reshape mining supply chains through a number of features as listed below $[105,108]$.

- On-demand and on-site production of components;

- Customisable and replicable bespoke components;

- Leaner and greener production to reduce waste, while ensuring quality.

\subsection{Tools and Moulds}

Metal AM is gradually being adopted by mould and tool makers. In this industry, metal AM is used to make tooling such as mould inserts, jigs, fixtures, and gauges $[109,110]$. Figure 10 shows an AM manufactured tool with conformal-cooling channels, which would 
be difficult to manufacture by conventional manufacturing techniques. This optimised component offers minimal warpage and reduced cycle time, and hence, improves the part quality and cooling process [111]. Another example is a 3D printed mould, which has a skeletal form including lattice-shell and rib reinforced structures. This AM mould provides fast and uniform cooling processes. Results showed that the new AM mould is 30\% more efficient than the original mould and has less deformation, residual stress, and casting defects [109].

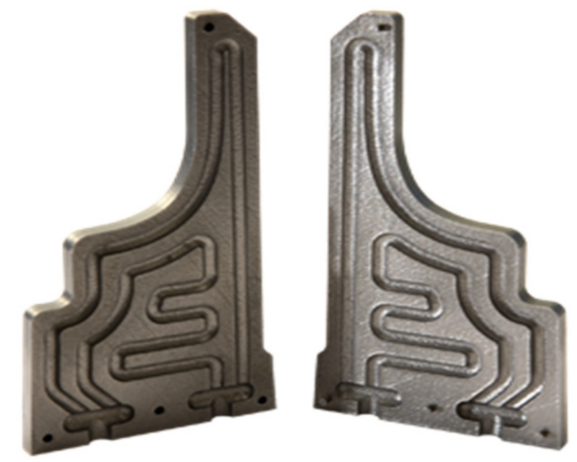

Figure 10. AM tool and die with conformal cooling channels [111].

\subsection{Railway}

The railway industry has started adopting AM technologies to carry out production and maintenance work. Alstom, a French multinational company, is adopting AM technologies for production of lightweight components [112]. Elsewhere, the MODTRAIN project has been financed by the European Commission to explore the standardisation/modularisation of rail components to reduce production, maintenance, and reliability costs. This has been further continued in a project entitled 'Run2Rail' in Europe where they are investigating the applications of AM technologies and composite material ap plications within the railway industry [112]. Another example is the initiatives undertaken by Dubai's Road Transport Authority's maintenance team to apply AM technologies with respect to various metro rail assets such as manufacturing AM parts for ticketing. Additionally, railway companies face problems in finding spare parts that have been discontinued or where the manufacturers are no longer in business, and which would be expensive to reproduce using conventional manufacturing [113]. To overcome this problem, the railway sector is now turning to metal AM. For example, Webtec, a global rail and transit manufacturer, is developing metal spare parts with GE's H2 Binder Jet technology. This company aims to use the $\mathrm{H} 2$ printer to produce up to 250 rail parts for its production lines by 2025 [114]. Similarly, Deutsche Bahn AG, a German railway company, in collaboration with Siemens produces spare parts for their older fleets [112,113].

Based on the above mentioned, it can be concluded that metal AM provides good opportunities for the railway industry. Interested readers may refer to the article published by Killen, Fu, Coxon, and Napper [112] for current AM applications in the railway industry sector.

\section{Challenges and Considerations}

Successful application of AM in industry requires an identification of the barriers to adoption, and a robust understanding of new technologies and their future impact at the early stage of decision making [115]. Therefore, this section addresses some important challenges relating to the adoption of metal AM technologies.

\subsection{Production Volume}

Most of the currently available metal AM technologies are only suitable for lowvolume production of customised products, and high complexity geometries [116]. This is, however, starting to change, with a number of companies introducing higher volume 
systems, such as HP's MJF systems, or Desktop Metal's Production System. Another relevant factor is that typically, the production cost using metal AM is higher than with conventional manufacturing systems due to the cost of materials and the difference in cycle time for components with similar geometry [117], and therefore metal AM is recommended for applications where higher flexibility and very low per part cost are not needed [118]. Clearly, there are still some barriers to the application of metal AM technologies in mass production. Nonetheless, the industrial application of metal AM in mass production is expanding due to new technological advances in the AM market [119].

\subsection{Standards Compliance}

The production environments of end-use metal AM require much higher precision than those for prototyping applications. Accordingly, qualification plays an important role in a production environment. This covers qualification of AM equipment, materials, and staff, and quality control techniques and instruments. The accuracy and repeatability of the manufactured products are important over the entire print, between prints, and across different makes of printer [120]. Currently, the incapability of metal AM to guarantee dimensional accuracy and material properties for a given product is an issue identified with respect to AM adoption in industry. One of the main reasons for this problem is the lack of widely accepted technical standards within metal AM [121]. These cause the following problems: datasets reported by different users are not comparable; little repetition of results exists between printer providers and service branches; different process parameters are employed to operate the same makes of equipment according to users' own requirements; few requirements exist to assure that a product is printed as specified; and consequently, the continued industrial adoption of metal AM is hindered. Figure 11 shows that the standardisation of AM has been undertaken mainly by the International Organisation for Standardisation (ISO) and the American Society for Testing and Materials (ASTM) [122]. The ISO working group, TC261, in collaboration with the ASTM F42 committee are developing AM standards, focusing processes, terms and definitions, process chains, test techniques, and quality controls. The European Committee for Standardisation (CEN) has also undertaken some activities with an AM scope on a regional level. Furthermore, a number of national standard organisations such as Deutsches Institut für Normung (DIN) and British Standards Institution (BSI) have published technical guidelines. Parallel to these activities, European Union projects are under development such as SASAM, Support Action for Standardisation in Additive Manufacturing, and STAIR AM, Standardisation, Innovation and Research. Although, a broad range of standards have been published in the AM field, some researchers believe that available standards require further improvement and development. For instance, Monzón et al. [121] highlighted that the available standards do not respond to AM's characteristics properly. This researcher conducted a survey in which 22 companies responded; approximately $50 \%$ of AM users mentioned that existing standards were not appropriately applicable and they proposed the development of standards for mechanical properties testing, printing parameters, and tolerance. The lack of these makes the qualification process difficult, particularly when it is mandatory for various industries such as medical, oil and gas, aerospace and automotive. However, it should be noted that the level of qualification is also important. A qualified part may not be sufficient for certain components such as fatigue critical aircraft components due to the presence of residual porosity and stress in some metal AM processes. Today, metal AM is moving towards industrial production. Therefore, the importance of technical standards including all views of metal AM technologies becomes more significant. Figure 12 shows the number of published and ongoing standards, which provides a clear understanding about the standardisation works within the scope of metal AM. These results were taken from 40 identified ISO and ASTM standards. The list of these standards is presented in the Appendix A for interested readers. Although $8 \%$ of the published identified standards is dedicated to the design area, $5 \%$ of standards in this area are under development, which highlights the importance of having new design guidelines for new technologies. 
Additionally, it can be seen that currently $45 \%, 35 \%$, and $8 \%$ of the metal standards are related to the materials and processes, testing methods and qualifications, and environment, respectively. This is due to the fact that there are still a number of gap areas concerning process control, geometric modelling and tolerancing, qualification techniques, printer calibration, heat treatment, surface finishing, and the material's characteristics such as flowability and morphology.

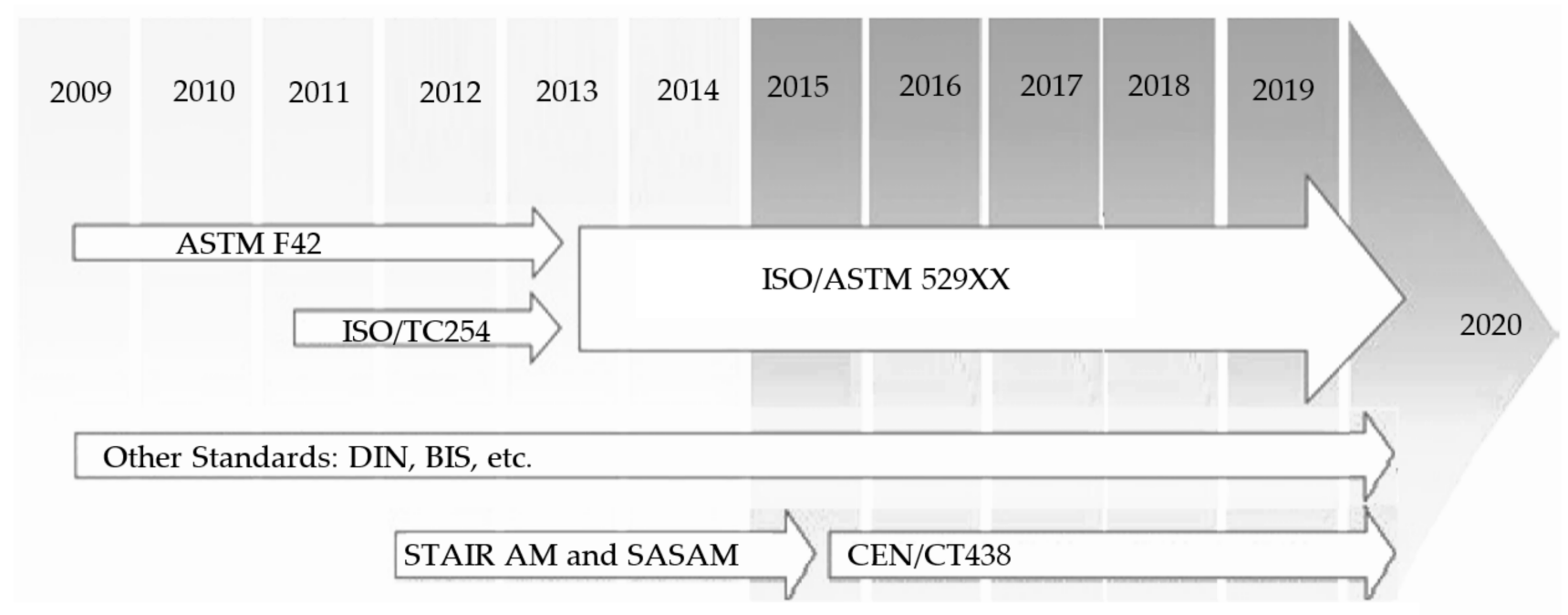

Figure 11. AM standardisation activities.

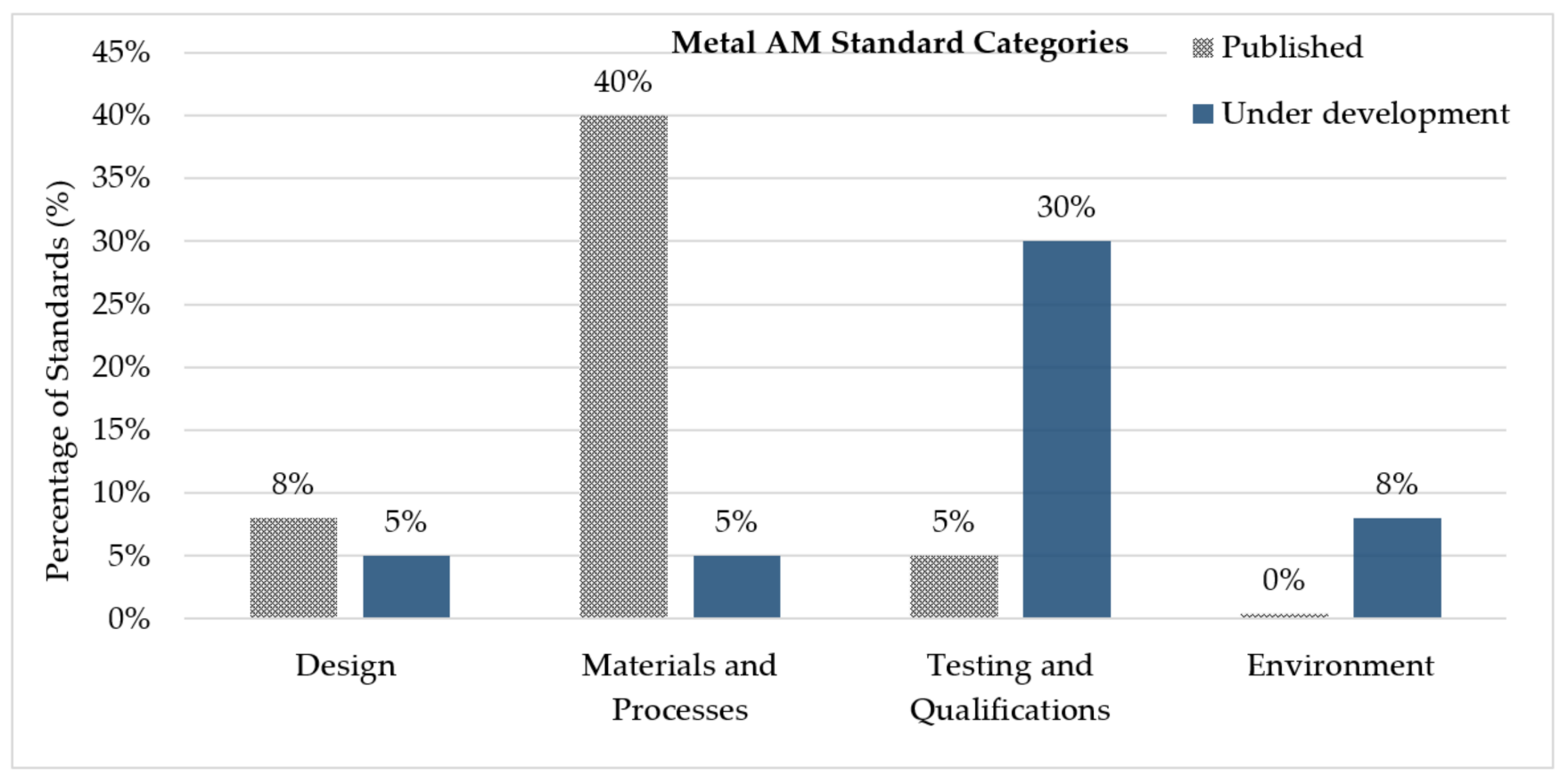

Figure 12. Current and under development metal AM 40 identified standards.

\subsection{Product Quality}

While metal AM offers great opportunities at the design stage, it lacks precision due to variations in mechanical properties [123], distorted geometry of the part [124]. Some researchers have found that metal AM products may have anisotropy and heterogeneity in microstructure and mechanical properties [123]. Indeed, the material properties do not remain the same after production; and material behaviour changes under cyclic thermal 
loading conditions [125]. Kok et al. [123] reviewed the mechanical properties of several metal AM products and believed that post processing operations such as heat treatment may provide the required mechanical properties. Clearly, inspections are required after production to identify defects such as voids, porosity, and undesirable grain characteristics. Another problem is the deviation of the printed part from its actual geometry and size. The precision and accuracy of metal AM technologies have been seriously restricted by geometric deviations and tolerances [126]. Besides these problems, distortions may be induced from residual stresses; and also the accuracy of the part can be affected by the slicing software causing the staircase effect [127]. Furthermore, transferring 3D CAD models into a 3D-printer format such as StereoLithogrAphy (STL) can result in some unexpected inaccuracies and defects, particularly in inclined and curved profiles [128]. Moreover, the variations in series of a specific printer and quality of calibration and setup may substantially change the product quality.

The above-mentioned problems cause challenges at the metrology and quality control stage. Quality is "the use of a standard against which other things of similar kind are compared" [129]. As such, the quality control is required to compare a company's metal AM products against the benchmark criteria. This is a key step in AM's development and commercialization pathways, to operating versions to show that a metal AM component has met required criteria. The challenge is the lack of widely accepted quality control methods, measurement techniques, and the need of greater data processing capabilities for organic and freeform external geometries fabricated with metal AM techniques. The fact is that the current measurement systems defined in the ISO standard did not consider complex freeform geometries. This becomes more challenging for internal shapes such as conformal cooling channels [130] and lattice structures [131], and it requires advanced imaging techniques such as computed tomography $[132,133]$. Furthermore, designers face difficulties to define "tolerance zone for these geometries [115]. However, some research has been done on geometric communicating techniques for complex and freeform profiles [134]. Clearly, to ensure more extensive adoption of metal AM in industry applications, the product quality and metrology techniques should be considered at the early design stage.

\subsection{Post Processing}

Depending on the metal AM technology, post processing operations are needed after each print. These operations may include powder removal, stress relief, part and support structure removal, machining operations, and the quality of parts by reducing or eliminating print-induced defects such as lack of fusion and porosity, but increases the cost of the process [135]. Among these operations, a stress relieving operation requires further attention and is generally needed for fabricated metal parts using most metal AM technologies, since residual stresses are caused by the rapid thermal cycles, and concurrent melting of the new layer and re-melting of the former solidified layers. This includes the following operations, which are used to reduce the interior defects, improve the microstructure and mechanical properties of AM parts, and are necessary for nearly all metal AM parts [136]: Hot isostatic pressing (HIP) is commonly used to release stresses, improve mechanical properties, and decrease any existing porosity for metal AM fabricated parts after the build [137]. In this process, high temperature and pressure were applied to the product in an inert environment [138]. In the most recent studies, the effect of the HIP method on microstructure and mechanical properties of different materials such as Ti6Al4V [139,140], Ni-base single crystal [141], ALSi10Mg [142] and copper [143] were investigated. In general, the results of these studies showed that in the following HIP treatment, the internal pores were reduced, and the tensile strength was reduced due to the microstructure changes. In contrast, the ductility was considerably improved for different materials. However, the results are dependent on the applied metal AM process, initial material properties and the selected metal AM process parameters. Therefore, it is recommended to perform a heat treatment operation after the HIP to enhance the effectiveness of the HIP process $[144,145]$. Heat treatment is used to improve surface 
quality and decrease residual stress gradients that can generate part distortion such as wraps and cracks that deteriorate the functionality of the end-use metal AM parts [146,147]. It should be noted that this process is best performed under a protective environment using an inert gas or a vacuum to minimise the chemical reactions [137]. Moreover, to improve dimensional accuracy, it is better to heat treat parts before finishing operations [148].

Laser processing is mainly used to improve the surface roughness, wear resistance, porosity, and microstructure of metal AM fabricated parts [149,150]. As shown in Figure 13a, during the process a melted thin layer is added to the surface using short laser pulses in a vacuum environment and at a low power density to make a smooth surface [151]. Cold rolling is commonly used for improving microstructure and geometry and reducing porosity of DED fabricated parts $[152,153]$. This is due to the fact that DED processes are used for the fabrication of large products and clearly the post-processing approaches are not the same as for other metal AM categories. To investigate the effect of the cold rolling operation on the large metal AM fabricated parts, Colegrove et al. [154] used different common rolling methods, which are schematically shown in Figure 13b. In this study Titanium and Aluminium were used. The results showed that rolling methods improved both the microstructure and mechanical properties of Titanium made parts significantly. The cold rolling approaches improved the mechanical properties of Aluminium made parts; however, the reduction of the porosity was considerable.

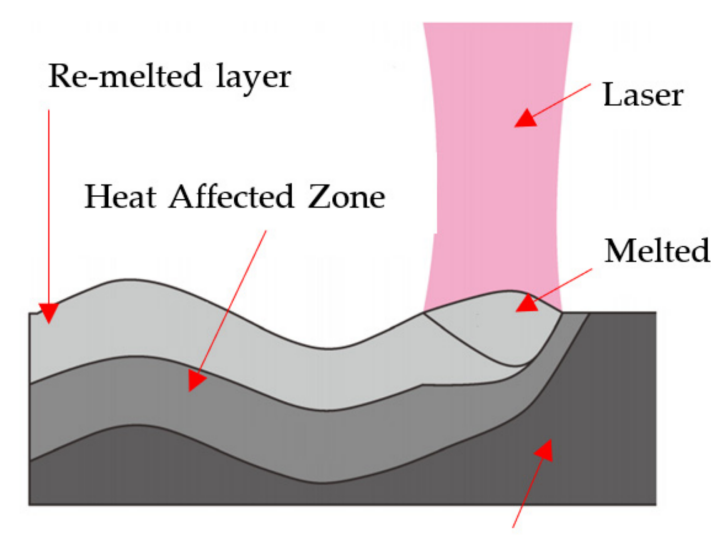

Metal AM Part

(a)
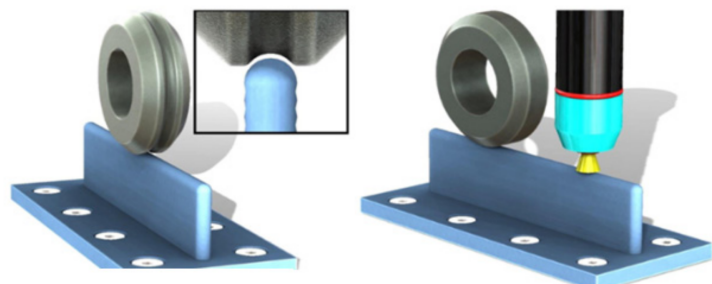

I. Vertical Profiled

II. In-situ
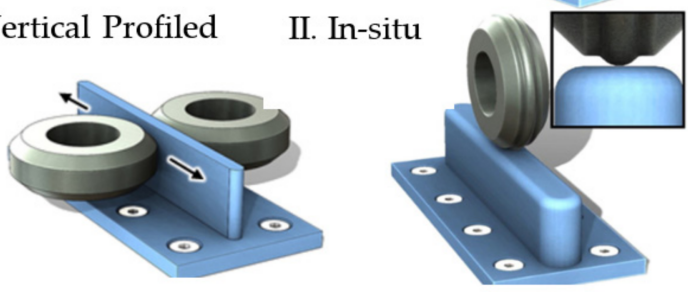

III. Pinch
IV. Inverted profiled

(b)

Figure 13. Post processing approaches: (a) Laser Polishing mechanism [155] and (b) Common cold rolling processes [154].

It should be note that the post processing operations may affect the dimensions of parts. To ensure dimensional accuracy of metal AM parts, surface finishing operations such as machining, chemical etching, and vibrating might be required [148]. The abovementioned needs increased lead time and costs; however, these may be minimised with further development of novel technologies and hybrid AM systems, and improvements in design software that can account for expected variations post production.

\subsection{Repairs and Maintenance}

Metal AM provides a great opportunity to consolidate components to minimise waste and weight. However, as-printed assemblies create a challenge for routine maintenance or repair as disassembling components becomes impossible [156]. In case of failures, the whole part must be replaced as the disassembling and reassembling of the consolidated part is impossible. In addition, it is difficult to disassemble and/or recycle embedded parts and multi-material assemblies [115]. Clearly, it increases waste and costs throughout the product lifecycle. Knofius et al. [157] analysed the total costs of consolidation with AM techniques, and concluded that consolidated and complex components lead to the rise on 
total costs than with conventional manufacturing design. To overcome these limitations, it is necessary to develop design strategies, optimisation techniques, and maintenance methodologies. It can be found that designers must have a picture of repair, maintenance, and disposal costs when evaluating the effects of design changes with AM.

\subsection{Limited Materials}

The number of materials for metal AM technologies is increasing; however, the current list of metals and alloys suitable for AM is limited. Today, designers can select from a range of metal materials such as Stainless Steel, Gold, Silver, Inconel, Copper, Titanium alloys, Nickle-based superalloys, tool steels, Aluminium alloys, Platinum, Palladium, and Tantalum $[158,159]$. Due to the limited metal materials for AM systems, research and development continues to expand materials, and adoption of current metal AM techniques to a broader range of materials. For instance, advanced research is being undertaken to develop high-entropy alloys [160], magnetic alloys [161], bulk metallic glasses (BMG) [162], functionally graded materials (FGM) [163], novel metal composite structures [164,165], and nano-architected metals [162]. Readers interested in recent developments of metallic alloys useful for AM systems are referred to Ngo et al. [166].

\subsection{Training and Skills}

One of the limitations to the exploitation of metal AM is the lack of a qualified and knowledgeable workforce, which requires specific training such as design for additive manufacturing (DFAM), materials, processes, machines, and maintenance and repair, management related to production, quality control and standards, cost modeling, and safety. Some researchers believed that the lack of public awareness, education programs, and appropriate skills prevent adoption of AM technologies [167]. Therefore, effective training programs are required to be developed [168], and a shift towards novel solutions integrating science, engineering, and management platforms is required to use fully the advantages and opportunities provided by metal AM technologies. To achieve this, Massachusetts Institute of Technology (MIT) has started a series of both face-to-face and online courses [169]. Moreover, other universities such as Missouri University of Science, University of Texas, University of Technology of Malaysia, and University of Virginia Technology, industry sectors such as Stratasys and private sectors such as Wohler's Associates have launched courses on aspects of AM. Go and Hart [169] provide further information on existing AM training programs.

\subsection{Size Limitation}

One of the critical barriers for application of metal AM is the maximum build volume, which gives the maximum size of the printed part. While metal AM processes can be divided into different sub-processes such as DED, EBEAM, etc. (see Table 1), not all systems are suitable for producing large parts [170]. Industry-wide, metal AM manufacturers continue to produce novel technologies to remain competitive and overcome industrial adoption challenges. Table 2 lists some recent metal AM systems that are commercially available for production of large parts. It should be noted that DED processes are mainly used for repair applications and less commonly for production of a whole part, primarily due to the lower accuracy and minimum feature size, and require post processing treatments [171]. 
Table 2. Metal AM machines for fabrication of large products.

\begin{tabular}{cccc}
\hline Machine Name & Manufacturer & Technology Type $\mathbf{~}^{\mathbf{B}}$ & $\begin{array}{c}\text { Build Size (mm } \times \\
\mathbf{m m} \times \mathbf{~ m m})\end{array}$ \\
\hline Kinetic Fusion & Titomic & DED & $9000 \times 3000 \times 1500$ \\
EBAM 300 Series & Sciaky & EBAM & $6096 \times 1194 \times 1524$ \\
SonicLayer 7000 & Fabrisonic & SL (UAM) & $1828 \times 1828 \times 914$ \\
AddCreator & ADIRA & SLM & $1000 \times 1000 \times 500$ \\
Lens 850-R & Optomec & LENS & $900 \times 1500 \times 900$ \\
MX-1000 & InssTek & DED (LMD) & $1000 \times 800 \times 650$ \\
ExOne M-Print & ExOne & MJ & $800 \times 500 \times 400$ \\
LUMEX Avance-60 & Matsuura & SLM & $600 \times 600 \times 500$ \\
SLM 500 H & SLM Solutions & SLM & $500 \times 280 \times 365$ \\
RMP1 & Aurora Labs & DMLM & $450 \times 450 \times 400$ \\
MetalFAB1 & Additive Industries & SLM & $420 \times 420 \times 400$ \\
M400 & EOS & DMLS & $400 \times 400 \times 400$ \\
Arcam Q20 & Arcam & EBM & $350 \times 380 \times 180$ \\
LightSPEE3D & SPEE3D & DED (supersonic 3D & $300 \times 300 \times 300$ \\
PAM Series M & Pollen AM & deposition) & $300 \times 300 \times 300$ \\
Metal X & Markforged & FDM & $250 \times 220 \times 200$ \\
\hline
\end{tabular}

${ }^{1}$ : Metal AM technologies have been classified in Table 1.

\subsection{Metal AM Costs}

To successfully apply metal AM in industry, AM products need to be feasible from a technical and economic perspective. Feasibility analysis is one of the necessary analyses, which facilitates enterprise decisions for manufacturing system selection [172]. Production of metal AM is not simple, nor cheap. This topic has received attention from researchers recently. For example, Kretzschmar et al. [173] developed a cost model for selecting the most optimal metal AM technologies. Sriram et al. [174] presented cost prediction models for metal powder machines. Additionally, Ulu et al. [175] believed that the total production cost of metal AM must be reduced; accordingly, they applied a process-based cost modeling (PBCM) to the metal AM topology optimization to reduce the total production cost, including material, labour, power, and equipment costs.

The literature review has revealed that the major contributor to the total metal AM production cost is the capital equipment cost [115]. Nowadays, there are many manufacturers that offer different types of metal AM systems. The price of metal 3D printers varies from AU $\$ 170,000$ (US\$ 115,000 ) to approximately AU $\$ 2.8$ million (US\$ 1.9 million) [5]. Therefore, prior to large-scale investment, the metal AM production costs for future products must be estimated and the products must be cost competitive against conventional manufacturing processes such as forging. However, the case for metal AM is a lot stronger for on-demand and/or on-site production, if waiting for replacements may have the potential to cause large delays and significant production losses.

Increased competition has resulted in a downward trend in machine prices, but only marginally thus far. In addition, the need for new gas lines, electrical works, industrial compressors, post processing machines, heat treatment furnaces, and annual service and maintenance costs must all be factored in. Additionally, if the weight of the machine exceeds five tons, special structural changes to the floor are required. The total cost also includes running costs such as buildings, materials and other consumables, energy consumption, personal protective equipment, and designing, testing and inspection, and post processing costs. Therefore, it is critical to identify all costs including the above items as well as any hidden elements related to the production of metal components for successful implementation. In addition, the development of a cost analysis model that estimates the production costs of a metal AM produced part versus a traditionally manufactured product is required, in such a model, using a sensitivity analysis to investigate various alternatives in the presence of uncertainty may lead to more robust results [176]. Impacts on supply 
chains, and the potential cost benefits of on demand production should also be factored into such models when assessing particular use cases [177].

\section{Conclusions and Future Work}

Metal AM has some advantages over conventional manufacturing techniques in the fabrication of novel geometries, complex structures, and customised parts with minimum waste. This paper provided a comprehensive review of common metal AM processes, including recent advancements and the current state of industrial applications. Moreover, the main challenges and considerations of the current metal AM status were outlined and discussed. It should be noted that advancements in metallic materials have considerably published by researchers. Therefore, this study does not address metallic materials and their properties in detail.

The leading industries in the metal AM market are the automotive, aerospace, medical, and dental industries. Over the recent years, metal AM has received attention from other industries such as oil and gas, electronics, construction, and railway to make significant inroads in the design and manufacturing of novel components. However, due to the drawbacks on printing quality, post processing, maintenance requirements, limited materials, geometry accuracy, part size limitations, standardisation, and costs, metal AM adoption has been slow. Continuous research and development in the metal AM field, including novel materials, design methods, and technologies have helped to overcome some of the discussed challenges and increase the industrial applications. Nevertheless, there are still some opportunities for improvement and further investigation. For example, the interrelations among metal AM processing parameters for each individual metal AM technology, mechanical properties, and geometry accuracy are still not fully understood. Accordingly, some theoretical models are required to be developed. These models may contain heat and mass transfer, porosity and residual stress prediction, distortion analysis, phase change, and so on. Sustainability issue for metal AM is another research gap to reduce wastage and energy consumption by using proper metal AM technologies and consequently employing just-in-time production. Additionally, fabricated metal AM part quality may be improved by using novel materials and/or processes, and topology optimisation techniques. Moreover, novel hybrid manufacturing may provide opportunities to improve a product's surface quality and repair and/or reshape existing products. In addition to the above potential research directions, optimisation analysis of process parameters and post-processing techniques are required for metal AM techniques to enhance the production efficiency. Moreover, further research is required to characterize the most important factors for metal AM adoption and develop a decision-making model to help industry sectors decide where metal AM would be best for them. Finally, establishing comprehensive widely accepted technical standards for metal AM is still an ongoing effort to assure the quality consistency of metal prints.

Author Contributions: Conceptualization, A.V. and F.G.; methodology, A.V.; validation, A.V., F.G. and A.R.; formal analysis, A.V.; investigation, A.V.; resources, A.V.; data curation, A.V.; writingoriginal draft preparation, A.V.; writing—review and editing, A.V., F.G., A.R. and K.H.; visualization, A.V.; supervision, A.R., F.G. and K.H.; funding acquisition, A.V. All authors have read and agreed to the published version of the manuscript.

Funding: This research was funded by the Edith Cowan University under Grant G1004423.

Acknowledgments: The first author would like to thank Stephen Newman from University of Bath, $\mathrm{UK}$, for his insightful advice and information on metal additive manufacturing. The first author would also like to thank Edith Cowan University for the awarded Vice-Chancellor research fund.

Conflicts of Interest: No potential conflict of interest was reported by the authors. 


\section{Appendix A}

Table A1. 40 identified current and under development standards for metal AM.

\begin{tabular}{|c|c|c|}
\hline Area. & Standard & Title \\
\hline \multirow{5}{*}{ Design } & ISO/ASTM 52911-1 & $\begin{array}{l}\text { Additive manufacturing-Design-Part 1: Laser-based powder bed } \\
\text { fusion of metals (published) }\end{array}$ \\
\hline & ASTM F3413-19 & $\begin{array}{l}\text { Guide for Additive Manufacturing-Design-Directed Energy } \\
\text { Deposition (published) }\end{array}$ \\
\hline & ISO/ASTM 52910 & Guidelines for Design for AM (published) \\
\hline & ISO/ASTM AWI 52909 & $\begin{array}{c}\text { Additive manufacturing-Finished part properties-Orientation and } \\
\text { location dependence of mechanical properties for metal powder bed } \\
\text { fusion (under development) }\end{array}$ \\
\hline & ISO/ASTM 52911-3 & $\begin{array}{l}\text { Additive manufacturing-Design-Part 3: Standard Guideline for } \\
\text { Electron-based powder bed fusion of metals (under development) }\end{array}$ \\
\hline \multirow{15}{*}{$\begin{array}{l}\text { Materials } \\
\text { and } \\
\text { Processes }\end{array}$} & ASTM F2924-14 & $\begin{array}{l}\text { Standard Specification for Additive Manufacturing Titanium -6 } \\
\text { Aluminum- } 4 \text { Vanadium with Powder Bed Fusion (published) }\end{array}$ \\
\hline & ISO/ASTM 52907 & $\begin{array}{l}\text { Additive manufacturing-Feedstock materials-Methods to } \\
\text { characterize metal powders (published) }\end{array}$ \\
\hline & ISO/ASTM 52904 & $\begin{array}{l}\text { Additive manufacturing-Process characteristics and } \\
\text { performance-Practice for metal powder bed fusion process to meet } \\
\text { critical applications (published) }\end{array}$ \\
\hline & ASTM F3001-14 & $\begin{array}{c}\text { Standard Specification for Additive Manufacturing Titanium -6 } \\
\text { Aluminum-4 Vanadium ELI (Extra Low Interstitial) with Powder Bed } \\
\text { Fusion (published) }\end{array}$ \\
\hline & ASTM F3049-14 & $\begin{array}{c}\text { Standard Guide for Characterizing Properties of Metal Powders Used } \\
\text { for Additive Manufacturing Processes (published) }\end{array}$ \\
\hline & ASTM F3055-14a & $\begin{array}{l}\text { Standard Specification for Additive Manufacturing Nickel Alloy } \\
\text { (UNS N06625) with Powder Bed Fusion (published) }\end{array}$ \\
\hline & ASTM F3434- 20 & $\begin{array}{l}\text { Guide for Additive manufacturing-Installation/Operation and } \\
\text { Performance Qualification (IQ/OQ/PQ) of Laser-Beam Powder Bed } \\
\text { Fusion Equipment for Production Manufacturing (Published) }\end{array}$ \\
\hline & ASTM F3187- 16 & Standard Guide for Directed Energy Deposition of Metals (published) \\
\hline & ASTM F3056- 14e1 & $\begin{array}{l}\text { Standard Specification for Additive Manufacturing Nickel Alloy } \\
\text { (UNS N07718) with Powder Bed Fusion (published) }\end{array}$ \\
\hline & ASTM F3184- 16 & $\begin{array}{l}\text { Standard Specification for Additive Manufacturing Stainless Steel } \\
\text { Alloy (UNS S31603) with Powder Bed Fusion (published) }\end{array}$ \\
\hline & ASTM F3213- 17 & $\begin{array}{l}\text { Standard for Additive Manufacturing-Finished Part } \\
\text { Properties-Standard Specification for Cobalt-28 Chromium-6 } \\
\text { Molybdenum via Powder Bed Fusion (published) }\end{array}$ \\
\hline & ASTM F3301-18a & $\begin{array}{c}\text { Standard for Additive Manufacturing-Post Processing } \\
\text { Methods-Standard Specification for Thermal Post-Processing Metal } \\
\text { Parts Made Via Powder Bed Fusion (published) }\end{array}$ \\
\hline & ASTM F3302- 18 & $\begin{array}{c}\text { Standard for Additive Manufacturing-Finished Part } \\
\text { Properties-Standard Specification for Titanium Alloys via Powder } \\
\text { Bed Fusion (published) }\end{array}$ \\
\hline & ASTM F3303- 18 & $\begin{array}{l}\text { Standard for Additive Manufacturing-Process Characteristics and } \\
\text { Performance: Practice for Metal Powder Bed Fusion Process to Meet } \\
\text { Critical Applications (published) }\end{array}$ \\
\hline & ISO/ASTM 52904- 19 & $\begin{array}{c}\text { Additive Manufacturing-Process Characteristics and Performance: } \\
\text { Practice for Metal Powder Bed Fusion Process to Meet Critical } \\
\text { Applications (published) }\end{array}$ \\
\hline
\end{tabular}


Table A1. Cont.

\begin{tabular}{|c|c|c|}
\hline Area. & Standard & Title \\
\hline & ASTM F3318- 18 & $\begin{array}{c}\text { Standard for Additive Manufacturing-Finished Part } \\
\text { Properties-Specification for AlSi10Mg with Powder Bed } \\
\text { Fusion—Laser Beam (published) }\end{array}$ \\
\hline & ISO/ASTM 52908 & $\begin{array}{l}\text { Additive manufacturing-Post-processing methods-Quality } \\
\text { assurance and post processing of powder bed fusion of metallic parts } \\
\text { (under development) }\end{array}$ \\
\hline & ISO/ASTM 52905 & $\begin{array}{l}\text { Additive manufacturing of metals-Non-destructive testing and } \\
\text { evaluation-Defect detection in parts (under development) }\end{array}$ \\
\hline \multirow{14}{*}{$\begin{array}{l}\text { Test and } \\
\text { Qualifica- } \\
\text { tions }\end{array}$} & ISO/ASTM 52941 & $\begin{array}{c}\text { Additive manufacturing-System performance and } \\
\text { reliability-Acceptance tests for laser metal powder-bed fusion } \\
\text { machines for metallic materials for aerospace application (published) }\end{array}$ \\
\hline & ISO/ASTM 52942 & $\begin{array}{l}\text { Additive manufacturing-Qualification principles-Qualifying } \\
\text { machine operators of laser metal powder bed fusion machines and } \\
\text { equipment used in aerospace applications (published) }\end{array}$ \\
\hline & ISO/ASTM 52907-19 & $\begin{array}{l}\text { Additive manufacturing-Feedstock materials-Methods to } \\
\text { characterize metallic powders materials (under development) }\end{array}$ \\
\hline & ISO/ASTM DIS 52941 & $\begin{array}{c}\text { Additive manufacturing-System performance and } \\
\text { reliability-Standard test method for acceptance of powder-bed } \\
\text { fusion machines for metallic materials for aerospace application } \\
\text { materials (under development) }\end{array}$ \\
\hline & ISO/ASTM 52908 & $\begin{array}{l}\text { Additive manufacturing-Post-processing methods-Standard } \\
\text { specification for quality assurance and post processing of powder } \\
\text { bed fusion metallic parts (under development) }\end{array}$ \\
\hline & ISO/ASTM DIS 52925 & $\begin{array}{c}\text { Additive manufacturing processes-Laser-based powder bed fusion } \\
\text { of polymer parts (PBF-LB/P)—Qualification of materials (under } \\
\text { development) }\end{array}$ \\
\hline & ISO/ASTM 52926-1 & $\begin{array}{l}\text { Additive manufacturing of metals-Qualification principles-Part 1: } \\
\text { General qualification of machine operators (under development) }\end{array}$ \\
\hline & ISO/ASTM 52926-2 & $\begin{array}{l}\text { Additive manufacturing of metals-Qualification principles-Part 2: } \\
\text { Qualification of machine operators for PBF-LB (under development) }\end{array}$ \\
\hline & ISO/ASTM 52926-3 & $\begin{array}{l}\text { Additive manufacturing of metals-Qualification principles-Part 3: } \\
\text { Qualification of machine operators for PBF-EB (under development) }\end{array}$ \\
\hline & ISO/ASTM 52926-4 & $\begin{array}{l}\text { Additive manufacturing of metals-Qualification principles-Part 4: } \\
\text { Qualification of machine operators for DED-LB (under development) }\end{array}$ \\
\hline & ISO/ASTM 52926-5 & $\begin{array}{c}\text { Additive manufacturing of metals-Qualification principles-Part 5: } \\
\text { Qualification of machine operators for DED-Arc (under } \\
\text { development) }\end{array}$ \\
\hline & ISO/ASTM 52928 & $\begin{array}{c}\text { Additive Manufacturing of Metals-Feedstock Materials-Powder } \\
\text { Life Cycle Management (under development) }\end{array}$ \\
\hline & ISO/ASTM 52935 & $\begin{array}{l}\text { Additive manufacturing-Qualification principles-Qualification of } \\
\text { coordinators for metallic parts production (under development) }\end{array}$ \\
\hline & ISO/ASTM 52936-1 & $\begin{array}{c}\text { Additive manufacturing-Qualification principles-Laser-based } \\
\text { powder bed fusion of polymers-Part 1: General principles, } \\
\text { preparation of test specimens (under development) }\end{array}$ \\
\hline \multirow{3}{*}{ Environment } & ISO/ASTM 52931 & $\begin{array}{l}\text { Additive manufacturing-Environmental health and safety-Part1 } \\
\text { Standard guideline for use of metallic materials (under development) }\end{array}$ \\
\hline & ISO/ASTM CD 52932 & $\begin{array}{c}\text { Additive manufacturing_Environmental health and safety-Part2 } \\
\text { (under development) }\end{array}$ \\
\hline & ISO/ASTM 52933 & $\begin{array}{c}\text { Additive manufacturing-Environmental health and safety-Part3 } \\
\text { (under development) }\end{array}$ \\
\hline
\end{tabular}

\section{References}

1. Saberi, S.; Mohd Yusu, R.; Zulkifli, N.; Megat Ahma, M. Effective factors on advanced manufacturing technology implementation performance: A review. J. Appl. Sci. 2010, 10, 1229-1242.

2. Citarella, R.; Giannella, V. Additive Manufacturing in Industry. Appl. Sci. 2021, 11, 840. [CrossRef]

3. ISO; ASTM. Additive Manufacturing-Design—Requirements, guidelines and recommendations. In ISO/ASTM 52910:2018(E); ISO: Geneva, Switzerland; ASTM: West Conshohocken, PA, USA, 2018. 
4. Wong, K.V.; Hernandez, A. A Review of Additive Manufacturing. ISRN Mech. Eng. 2012, 2012, 1-10. [CrossRef]

5. Wohlers, T.; Campbell, I.; Diegel, O.; Huff, R.; Kowen, J. 3D Printing and Additive Manufacturing State of the Industry: Annual Worldwide Progress Report; Lund University: Lund, Sweden, 2017.

6. Huang, R.; Riddle, M.; Graziano, D.; Warren, J.; Das, S.; Nimbalkar, S.; Cresko, J.; Masanet, E. Energy and emissions saving potential of additive manufacturing: The case of lightweight aircraft components. J. Clean. Prod. 2016, 135, 1559-1570.

7. Rejeski, D.; Zhao, F.; Huang, Y. Research needs and recommendations on environmental implications of additive manufacturing. Addit. Manuf. 2018, 19, 21-28.

8. Galante, R.; Figueiredo-Pina, C.G.; Serro, A.P. Additive manufacturing of ceramics for dental applications: A review. Dent. Mater 2019, 35, 825-846.

9. Buchanan, C.; Gardner, L. Metal 3D printing in construction: A review of methods, research, applications, opportunities and challenges. Eng. Struct. 2019, 180, 332-348.

10. Najmon, J.C.; Raeisi, S.; Tovar, A. Review of additive manufacturing technologies and applications in the aerospace industry. In Additive Manufacturing for the Aerospace Industry; Elsevier: Amsterdam, The Netherlands, 2019; pp. 7-31.

11. Ahn, D.-G. Direct metal additive manufacturing processes and their sustainable applications for green technology: A review. Int. J. Precis. Eng. Manuf. Green Technol. 2016, 3, 381-395.

12. Pan, Z.; Ding, D.; Wu, B.; Cuiuri, D.; Li, H.; Norrish, J. Arc welding processes for additive manufacturing: A review. In Transactions on Intelligent Welding Manufacturing; Springer: Berlin/Heidelberg, Germany, 2018; pp. 3-24.

13. Ziaee, M.; Crane, N.B. Binder jetting: A review of process, materials, and methods. Addit. Manuf. 2019, 28, 781-801. [CrossRef]

14. Wu, Q.; Mukherjee, T.; Liu, C.; Lu, J.; DebRoy, T. Residual stresses and distortion in the patterned printing of titanium and nickel alloys. Addit. Manuf. 2019, 29, 100808. [CrossRef]

15. Yakout, M.; Elbestawi, M.; Veldhuis, S.C. A review of metal additive manufacturing technologies. Solid State Phenom. 2018, 1-14.

16. DebRoy, T.; Wei, H.; Zuback, J.; Mukherjee, T.; Elmer, J.; Milewski, J.; Beese, A.M.; Wilson-Heid, A.; De, A.; Zhang, W. Additive manufacturing of metallic components-process, structure and properties. Prog. Mater. Sci. 2018, 92, 112-224.

17. Ransikarbum, K.; Pitakaso, R.; Kim, N. A Decision-Support Model for Additive Manufacturing Scheduling Using an Integrative Analytic Hierarchy Process and Multi-Objective Optimization. Appl. Sci. 2020, 10, 5159.

18. Cherdo, L. The Best Metal 3D Printers in 2020. Available online: https://www.aniwaa.com/best-of/3d-printers/best-metal-3dprinter/ (accessed on 8 January 2021).

19. Piñero Vega, D.; Batista Ponce, M.; Valerga Puerta, A.P.; Vazquez Martinez, J.M.; Fernandez Vidal, S.R. A Comparison of Macro and Microgeometrical Properties of Specimens Made with a FDM Commercial Printer and Its Opensource Retrofit Version. Ann. DAAAM Proc. 2018, 29, 1108-1115.

20. Riecker, S.; Clouse, J.; Studnitzky, T.; Andersen, O.; Kieback, B. Fused Deposition Modeling-Opportunities for Cheap Metal AM. In Proceedings of the World PM 2016 Congress and Exhibition, Hamburg, Germany, 9-13 October 2016; pp. 1-19.

21. Hwang, S.; Reyes, E.I.; Moon, K.-S.; Rumpf, R.C.; Kim, N.S. Thermo-mechanical characterization of metal/polymer composite filaments and printing parameter study for fused deposition modeling in the 3D printing process. J. Electron. Mater. 2015, 44, 771-777.

22. Patterson, A.E.; Messimer, S.L.; Farrington, P.A. Overhanging features and the SLM/DMLS residual stresses problem: Review and future research need. Technologies 2017, 5, 15.

23. Delgado, J.; Ciurana, J.; Rodríguez, C.A. Influence of process parameters on part quality and mechanical properties for DMLS and SLM with iron-based materials. Int. J. Adv. Manuf. Technol. 2012, 60, 601-610.

24. Berlier, J.; McCann, A.; Zhang, L.; Good, B. Systems and Methods for Receiving Sensor Data for an Operating Additive Manufacturing Machine and Adaptively Compressing the Sensor Data Based on Process Data which Controls the Operation of the Machine. Google Patents US20180348734A1, 6 December 2018.

25. Jeong, H.Y.; An, S.-C.; Lim, Y.; Jeong, M.J.; Kim, N.; Jun, Y.C. 3D and 4D Printing of Multistable Structures. Appl. Sci. 2020, 10,7254 .

26. Hu, G.; Cao, Z.; Hopkins, M.; Lyons, J.G.; Brennan-Fournet, M.; Devine, D.M. Nanofillers can be used to enhance the thermal conductivity of commercially available SLA resins. Procedia Manuf. 2019, 38, 1236-1243.

27. Caccia, M.; Tabandeh-Khorshid, M.; Itskos, G.; Strayer, A.; Caldwell, A.; Pidaparti, S.; Singnisai, S.; Rohskopf, A.; Schroeder, A.; Jarrahbashi, D. Ceramic-metal composites for heat exchangers in concentrated solar power plants. Nature 2018, $562,406$.

28. Sakly, A.; Kenzari, S.; Bonina, D.; Corbel, S.; Fournée, V. A novel quasicrystal-resin composite for stereolithography. Mater. Des. (1980-2015) 2014, 56, 280-285.

29. Roberson, D.A.; Perez, A.R.T.; Rocha, C.R. Methods and Compositions for Material Extrusion 3D Printing. Google Patents US20160160073A1, 9 June 2016.

30. Leong, D. Types of 3D Printing in Metal. Available online: https://markforged.com/learn/types-of-3d-printing-metal/ (accessed on 3 October 2020).

31. Bidare, P.; Bitharas, I.; Ward, R.; Attallah, M.; Moore, A.J. Fluid and particle dynamics in laser powder bed fusion. Acta Mater. 2018, 142, 107-120.

32. Chen, C.; Gojon, S.; Xie, Y.; Yin, S.; Verdy, C.; Ren, Z.; Liao, H.; Deng, S. A novel spiral trajectory for damage component recovery with cold spray. Surf. Coat. Technol. 2017, 309, 719-728. 
33. Yan, X.; Huang, C.; Chen, C.; Bolot, R.; Dembinski, L.; Huang, R.; Ma, W.; Liao, H.; Liu, M. Additive manufacturing of WC reinforced maraging steel 300 composites by cold spraying and selective laser melting. Surf. Coat. Technol. 2019, 371, $161-171$.

34. Cunningham, C.; Flynn, J.; Shokrani, A.; Dhokia, V.; Newman, S. Invited review article: Strategies and processes for high quality wire arc additive manufacturing. Addit. Manuf. 2018, 22, 672-686.

35. Wu, B.; Pan, Z.; Ding, D.; Cuiuri, D.; Li, H.; Xu, J.; Norrish, J. A review of the wire arc additive manufacturing of metals: Properties, defects and quality improvement. J. Manuf. Process. 2018, 35, 127-139.

36. Meisel, N.A.; Dillard, D.A.; Williams, C.B. Impact of material concentration and distribution on composite parts manufactured via multi-material jetting. Rapid Prototyp. J. 2018, 24, 872-879.

37. Miyanaji, H.; Momenzadeh, N.; Yang, L. Effect of printing speed on quality of printed parts in Binder Jetting Process. Addit. Manuf. 2018, 20, 1-10.

38. Wheat, E.; Vlasea, M.; Hinebaugh, J.; Metcalfe, C. Sinter structure analysis of titanium structures fabricated via binder jetting additive manufacturing. Mater. Des. 2018, 156, 167-183.

39. White, D. Ultrasonic Object Consolidation. Google Patents US6519500B1, 11 February 2003.

40. Guo, H.; Gingerich, M.B.; Haedings, L.M.; Hahnlen, R.; Dapino, M.J. Joining of carbon fiber and aluminum using ultrasonic additive manufacturing (UAM). Compos. Struct. 2019, 208, 180-188. [CrossRef]

41. Hafkamp, T.; van Baars, G.; de Jager, B.; Etman, P. A feasibility study on process monitoring and control in vat photopolymerization of ceramics. Mechatronics 2018, 56, 220-241.

42. Diegel, O.; Nordin, A.; Motte, D. Additive Manufacturing Technologies. In A Practical Guide to Design for Additive Manufacturing; Springer: Singapore, 2019; pp. 19-39. [CrossRef]

43. Barbosa de Lima, J.C. Laminated Object Manufacturing. Available online: https://www.manufacturingguide.com/en/laminatedobject-manufacturing-lom (accessed on 25 April 2020).

44. Calignano, F.; Manfredi, D.; Ambrosio, E.P.; Biamino, S.; Lombardi, M.; Atzeni, E.; Salmi, A.; Minetola, P.; Iuliano, L.; Fino, P. Overview on additive manufacturing technologies. Proc. IEEE 2017, 105, 593-612.

45. Choi, Y.; Lee, D.-G. Correlation between surface tension and fatigue properties of Ti-6Al-4V alloy fabricated by EBM additive manufacturing. Appl. Surf. Sci. 2019, 481, 741-746.

46. Dass, A.; Moridi, A. State of the art in directed energy deposition: From additive manufacturing to materials design. Coatings 2019, 9, 418.

47. Villafuerte, J. Considering cold spray for additive manufacturing. Adv. Mater. Process. 2014, 50, 50-52.

48. Bento, J.B.; Lopez, A.; Pires, I.; Quintino, L.; Santos, T.G. Non-destructive testing for wire+ arc additive manufacturing of aluminium parts. Addit. Manuf. 2019, 29, 100782.

49. Urhal, P.; Weightman, A.; Diver, C.; Bartolo, P. Robot assisted additive manufacturing: A review. Robot. Comput. Integr. Manuf. 2019, 59, 335-345.

50. McCallum, D. A Radically Simple New Technology for Fast, Low-Cost Metal Additive Manufacturing. Available online: https:/ / www.digitalalloys.com/blog/joule-printing/ (accessed on 23 September 2019).

51. Chiumenti, M.; Lin, X.; Cervera, M.; Lei, W.; Zheng, Y.; Huang, W. Numerical simulation and experimental calibration of Additive Manufacturing by blown powder technology. Part I: Thermal analysis. Rapid Prototyp. J. 2017, 23, 448-463.

52. Onuike, B.; Heer, B.; Bandyopadhyay, A. Additive manufacturing of Inconel 718 - copper alloy bimetallic structure using laser engineered net shaping (LENS ${ }^{\mathrm{TM}}$ ). Addit. Manuf. 2018, 21, 133-140.

53. Löffler, K. Developments in disk laser welding. In Handbook of Laser Welding Technologies; Elsevier: Amsterdam, The Netherlands, 2013; pp. 73-102. [CrossRef]

54. Rahmati, S. Advances in Additive Manufacturing and Tooling. Compr. Mater. Process. 2014, 10, 303-344. [CrossRef]

55. Zenou, M.; Grainger, L. Additive manufacturing of metallic materials. In Additive Manufacturing; Elsevier: Amsterdam, The Netherlands, 2018; pp. 53-103.

56. Ghosal, P.; Majumder, M.C.; Chattopadhyay, A. Study on direct laser metal deposition. Mater. Today Proc. 2018, 5, $12509-12518$.

57. Vinogradov, P. 3D Printing in Medicine: Current Challenges and Potential Applications. In 3D Printing Technology in Nanomedicine; Elsevier: Amsterdam, The Netherlands, 2019; p. 1.

58. Lee, J.; Chung, H. Experimental Investigation of Deposition Pattern on the Temperature and Distortion of Direct Energy Deposition-Based Additive Manufactured Part. Appl. Sci. 2020, 10, 7653.

59. Calleja, A.; Tabernero, I.; Ealo, J.A.; Campa, F.J.; Lamikiz, A.; de Lacalle, L.N.L. Feed rate calculation algorithm for the homogeneous material deposition of blisk blades by 5-axis laser cladding. Int. J. Adv. Manuf. Technol. 2014, 74, 1219-1228.

60. Donadello, S.; Motta, M.; Demir, A.G.; Previtali, B. Monitoring of laser metal deposition height by means of coaxial laser triangulation. Opt. Lasers Eng. 2019, 112, 136-144.

61. Selcuk, C. Joining processes for powder metallurgy parts. In Advances in Powder Metallurgy; Elsevier: Amsterdam, The Netherlands, 2013; pp. 380-398.

62. Liu, J.; Yu, H.; Chen, C.; Weng, F.; Dai, J. Research and development status of laser cladding on magnesium alloys: A review. Opt. Lasers Eng. 2017, 93, 195-210.

63. Toyserkani, E.; Khajepour, A.; Corbin, S.F. Laser Cladding; CRC Press: Boca Raton, FL, USA, 2004.

64. Yue, T.; Su, Y.; Yang, H. Laser cladding of Zr65Al7. 5Ni10Cu17. 5 amorphous alloy on magnesium. Mater. Lett. 2007, 61, 209-212.

65. Tabernero, I.; Calleja, A.; Lamikiz, A.; De Lacalle, L.L. Optimal parameters for 5-axis laser cladding. Procedia Eng. 2013, 63, 45-52. 
66. Flynn, J.M.; Shokrani, A.; Newman, S.T.; Dhokia, V. Hybrid additive and subtractive machine tools—Research and industrial developments. Int. J. Mach. Tools Manuf. 2016, 101, 79-101.

67. Wang, Y.; Lin, Y.; Zhong, R.Y.; Xu, X. IoT-enabled cloud-based additive manufacturing platform to support rapid product development. Int. J. Prod. Res. 2019, 57, 3975-3991.

68. Jensen, W. Automotive: Formula Student Germany-EOS Supports Racing Team by Producing a Topology-Optimized Steering Stub Axle. Available online: https://www.eos.info/press/customer_case_studies/rennteam_uni_stuttgart (accessed on 18 June 2020).

69. Bakewell, J. Customising Production. Available online: https://www.automotivemanufacturingsolutions.com/customisingproduction/31218.article (accessed on 4 February 2020).

70. Tyrrell, M. Use of 3D Printed Components at BMW Jumps 42\% Annually. Available online: https://www.pesmedia.com/3dprinting-components-bmw-group / (accessed on 12 July 2020).

71. Anusci, V. BMW's New S58 Engine Features Cylinder Head Made with 3D Printing. Available online: https://www. 3dprintingmedia.network/bmw-s58-engine-3d-printed-cylinder/ (accessed on 2 November 2020).

72. Wischeropp, T.M.; Hoch, H.; Beckmann, F.; Emmelmann, C. Opportunities for Braking Technology Due to Additive Manufacturing Through the Example of a Bugatti Brake Caliper. In Proceedings of the XXXVII Internationales $\mu$-Symposium 2018 BremsenFachtagung, Bad Neuenahr, Germany, 26 October 2018; pp. 181-193.

73. Csere, C. How Automakers Are 3D-Printing Parts for Production Cars. Available online: https://www.caranddriver.com/ features/a20684648/how-automakers-are-3d-printing-parts-for-production-cars-and-classics/ (accessed on 12 May 2020).

74. Tucker, E. APWorks Creates Light Rider 3D-Printed Motorcycle. Available online: https://www.dezeen.com/2016/06/06/lightrider-apworks-3d-printed-electric-motorcycle-aluminium/ (accessed on 3 September 2019).

75. Awd, M.; Tenkamp, J.; Hirtler, M.; Siddique, S.; Bambach, M.; Walther, F. Comparison of microstructure and mechanical properties of Scalmalloy®produced by selective laser melting and laser metal deposition. Materials 2018, 11, 17.

76. Singamneni, S.; Yifan, L.; Hewitt, A.; Chalk, R.; Thomas, W. Additive Manufacturing for the Aircraft Industry: A Review. J. Aeronaut Aerosp. Eng. 2019, 8. [CrossRef]

77. Kellner, T. 3D-Printed 'Bionic' Parts Could Revolutionize Aerospace Design; General Electric Reports: Boston, MA, USA, 2017.

78. Russell, R.; Wells, D.; Waller, J.; Poorganji, B.; Ott, E.; Nakagawa, T.; Sandoval, H.; Shamsaei, N.; Seifi, M. Qualification and certification of metal additive manufactured hardware for aerospace applications. In Additive Manufacturing for the Aerospace Industry; Elsevier: Amsterdam, The Netherlands, 2019; pp. 33-66.

79. González-Barrio, H.; Calleja-Ochoa, A.; Lamikiz, A.; López de Lacalle, L. Manufacturing Processes of Integral Blade Rotors for Turbomachinery, Processes and New Approaches. Appl. Sci. 2020, 10, 3063.

80. Ruiz-Salas, J.; Gonzalez-Barrio, H.; Calleja-Ochoa, A.; Ukar-Arrien, E.; Lamikiz-Mentxaka, A. Turbo engine components repair methodology by laser material deposition. DYNA 2018, 93, 643-648.

81. Wilson, J.M.; Piya, C.; Shin, Y.C.; Zhao, F.; Ramani, K. Remanufacturing of turbine blades by laser direct deposition with its energy and environmental impact analysis. J. Clean. Prod. 2014, 80, 170-178.

82. Raja, V.; Zhang, S.; Garside, J.; Ryall, C.; Wimpenny, D. Rapid and cost-effective manufacturing of high-integrity aerospace components. Int. J. Adv. Manuf. Technol. 2006, 27, 759-773.

83. Graves, J. Nexxt Spine Develops AM Spinal Implants Using MTS Test Systems; Nexxt Spine: Noblesville, IN, USA, 2019 ; p. 89.

84. Harrysson, O.L.; Marcellin-Little, D.J.; Horn, T.J. Applications of metal additive manufacturing in veterinary orthopedic surgery. JOM 2015, 67, 647-654.

85. Vilardell, A.; Takezawa, A.; du Plessis, A.; Takata, N.; Krakhmalev, P.; Kobashi, M.; Yadroitsava, I.; Yadroitsev, I. Topology optimization and characterization of Ti6Al4V ELI cellular lattice structures by laser powder bed fusion for biomedical applications. Mater. Sci. Eng. A 2019, 766, 138330.

86. Kain, M.; Nadimpalli, V.; Miqueo, A.; May, M.; Yagüe-Fabra, J.; Häfner, B.; Pedersen, D.; Calaon, M.; Tosello, G. Metal Additive Manufacturing of Multi-Material Dental Strut Implants. In Proceedings of the 20th International Conference of the European Society for Precision Engineering and Nanotechnology (EUSPEN 20), Geneva, Switzerland, 8-12 June 2020.

87. Revilla-León, M.; Sadeghpour, M.; Özcan, M. A Review of the Applications of Additive Manufacturing Technologies Used to Fabricate Metals in Implant Dentistry. J. Prosthodont. 2020, 29, 579-593.

88. Camacho, D.D.; Clayton, P.; O’Brien, W.; Ferron, R.; Juenger, M.; Salamone, S.; Seepersad, C. Applications of additive manufacturing in the construction industry-A prospective review. In Proceedings of the 34th International Symposium on Automation and Robotics in Construction and Mining (ISARC 2017), Taipei, Taiwan, 27-30 June 2017.

89. Strauss, H.; Knaack, U. Additive Manufacturing for Future Facades: The potential of 3D printed parts for the building envelope. J. Facade Des. Eng. 2015, 3, 225-235.

90. Espera, A.H.; Dizon, J.R.C.; Chen, Q.; Advincula, R.C. 3D-printing and advanced manufacturing for electronics. Prog. Addit. Manuf. 2019, 1-23. [CrossRef]

91. Lewis, J.A.; Ahn, B.Y. Device fabrication: Three-dimensional printed electronics. Nature 2015, 518, 42.

92. Saengchairat, N.; Tran, T.; Chua, C.-K. A review: Additive manufacturing for active electronic components. Virtual Phys. Prototyp. 2017, 12, 31-46.

93. Gjokaj, V.; Papapolymerou, J.; Albrecht, J.D.; Chahal, P. Design and Fabrication of Additively Manufactured Hybrid Rigid-Flex RF Components. IEEE Trans. Compon. Packag. Manuf. Technol. 2019, 9, 779-785. 
94. Yosui, K.; Morita, I. Antenna Element and Method of Manufacturing the Same. Google Patents US10283855B2, 7 May 2019.

95. Goh, G.L.; Ma, J.; Chua, K.L.F.; Shweta, A.; Yeong, W.Y.; Zhang, Y.P. Inkjet-printed patch antenna emitter for wireless communication application. Virtual Phys. Prototyp. 2016, 11, 289-294.

96. Optisys. Additive Manufacturing Transforms RF Antenna Design. Available online: https://www.metal-am.com/additivemanufacturing-transforms-rf-antenna-design/ (accessed on 6 September 2019).

97. Verploegh, S.; Coffey, M.; Grossman, E.; Popović, Z. Properties of 50-110-GHz waveguide components fabricated by metal additive manufacturing. IEEE Trans. Microw. Theory Tech. 2017, 65, 5144-5153.

98. Sher, D. The State of AM in the Oil and Gas Industry. Available online: https://www.3dprintingmedia.network/new-smartechanalysis-report-on-am-in-the-oil-and-gas-industry-finds-1b-opportunity-am-hardware/ (accessed on 6 September 2019).

99. Burns, M.; Wangenheim, C. Metal 3D Printing Applications in the Oil \& Gas Industry. In Proceedings of the SPE Middle East Oil and Gas Show and Conference, Manama, Bahrain, 18-21 March 2019.

100. Sireesha, M.; Lee, J.; Kiran, A.S.K.; Babu, V.J.; Kee, B.B.; Ramakrishna, S. A review on additive manufacturing and its way into the oil and gas industry. RSC Adv. 2018, 8, 22460-22468.

101. Lloyd's. First Additively Manufactured Part for Oil and Gas Certified. Available online: https://www.lr.org/en/latest-news/ first-additively-manufactured-part-for-oil-and-gas-certified-by-lr/ (accessed on 3 March 2020).

102. Barnes, J.B.; Camisa, J.A. Additive Manufacturing for Oil and Gas-Potential of Topology Optimization for Offshore Applications. In Proceedings of the 29th International Ocean and Polar Engineering Conference, Honolulu, HI, USA, 16-21 June 2019.

103. Siemens. Fast, Efficient, Flexible: Additive Manufacturing (3D-Printing) in the Energy Sector. Available online: https: //new.siemens.com/global/en/products/energy/services/maintenance/parts/additive-manufacturing.html (accessed on 21 November 2020).

104. Frandsen, C.S.; Nielsen, M.M.; Chaudhuri, A.; Jayaram, J.; Govindan, K. In search for classification and selection of spare parts suitable for additive manufacturing: A literature review. Int. J. Prod. Res. 2020, 58, 970-996.

105. Lempriere, M. A Project to Save Time and Energy with 3D Printed Mining Parts. Available online: https://www.miningtechnology.com/digital-disruption/3d-printed-mining-parts / (accessed on 3 September 2019).

106. Jamasmie, C. Sandvik Invests $\$ 25$ Million to Boost Use of Metal 3D Printing. Available online: https://www.mining.com/ sandvik-invests-25-million-to-boost-use-of-metal-3d-printing/ (accessed on 3 September 2019).

107. Scott, C. 3D Printing and Internet of Things to Revolutionize Mining. Available online: https://3dprint.com/215374/3d-printingiot-mining/ (accessed on 3 September 2019).

108. Ligon, S.C.; Liska, R.; Stampfl, J.R.; Gurr, M.; Mülhaupt, R. Polymers for 3D printing and customized additive manufacturing. Chem. Rev. 2017, 117, 10212-10290.

109. Kang, J.; Shangguan, H.; Deng, C.; Hu, Y.; Yi, J.; Wang, X.; Zhang, X.; Huang, T. Additive manufacturing-driven mold design for castings. Addit. Manuf. 2018, 22, 472-478.

110. Le Néel, T.A.; Mognol, P.; Hascoët, J.-Y. A review on additive manufacturing of sand molds by binder jetting and selective laser sintering. Rapid Prototyp. J. 2018, 24, 1325-1336.

111. Intech DMLS. Tool and Die Conformal Cooling. Available online: https://intech-dmls.in/additive-manufacturing/ (accessed on 6 September 2019).

112. Killen, A.; Fu, L.; Coxon, S.; Napper, R. Exploring the use of Additive Manufacturing in Providing an Alternative Approach to the Design, Manufacture and Maintenance of Interior Rail Components. In Proceedings of the 40th Australasian Transport Research Forum (ATRF 2018), Darwin, Australia, 30 October-1 November 2018.

113. Kingsland, P. 3D Printing in the Railway Sector with Deutsche Bahn. Available online: https://www.railway-technology.com/ features/3d-printing-in-the-railway-sector/ (accessed on 6 September 2019).

114. Colyer, J. Wabtec Brings Industrial 3D Printing to the Rail Industry with Purchase of GE's H2. Available online: https:// 3dprintingindustry.com/news / wabtec-brings-industrial-3d-printing-to-the-rail-industry-with-purchase-of-ges-h2-155703/ (accessed on 6 September 2019).

115. Thompson, M.K.; Moroni, G.; Vaneker, T.; Fadel, G.; Campbell, R.I.; Gibson, I.; Bernard, A.; Schulz, J.; Graf, P.; Ahuja, B. Design for Additive Manufacturing: Trends, opportunities, considerations, and constraints. CIRP Ann. 2016, 65, 737-760.

116. Yamazaki, T. Development of a hybrid multi-tasking machine tool: Integration of additive manufacturing technology with $\mathrm{CNC}$ machining. Procedia CIRP 2016, 42, 81-86.

117. Thompson, A.; Maskery, I.; Leach, R.K. X-ray computed tomography for additive manufacturing: A review. Meas. Sci. Technol. 2016, 27, 072001.

118. Gupta, N.; Weber, C.; Newsome, S. Additive manufacturing: Status and opportunities. Sci. Technol. Policy Inst. Wash. 2012, 1-29.

119. Dilberoglu, U.M.; Gharehpapagh, B.; Yaman, U.; Dolen, M. The role of additive manufacturing in the era of industry 4.0. Procedia Manuf. 2017, 11, 545-554.

120. Huang, Y.; Leu, M.C.; Mazumder, J.; Donmez, A. Additive manufacturing: Current state, future potential, gaps and needs, and recommendations. J. Manuf. Sci. Eng. 2015, 137, 014001.

121. Monzón, M.; Ortega, Z.; Martínez, A.; Ortega, F. Standardization in additive manufacturing: Activities carried out by international organizations and projects. Int. J. Adv. Manuf. Technol. 2015, 76, 1111-1121.

122. Lee, B.N.; Pei, E.; Um, J. An overview of information technology standardization activities related to additive manufacturing. Prog. Addit. Manuf. 2019, 1-10. [CrossRef] 
123. Kok, Y.; Tan, X.P.; Wang, P.; Nai, M.; Loh, N.H.; Liu, E.; Tor, S.B. Anisotropy and heterogeneity of microstructure and mechanical properties in metal additive manufacturing: A critical review. Mater. Des. 2018, 139, 565-586.

124. Kumar, H.A.; Kumaraguru, S. Distortion in Metal Additive Manufactured Parts. In 3D Printing and Additive Manufacturing Technologies; Springer: Berlin/Heidelberg, Germany, 2019; pp. 281-295.

125. Seifi, M.; Gorelik, M.; Waller, J.; Hrabe, N.; Shamsaei, N.; Daniewicz, S.; Lewandowski, J.J. Progress towards metal additive manufacturing standardization to support qualification and certification. JOM 2017, 69, 439-455.

126. Xiao, J.; Anwer, N.; Durupt, A.; Le Duigou, J.; Eynard, B. Information exchange standards for design, tolerancing and additive manufacturing: A research review. Int. J. Interact. Des. Manuf. (IJIDeM) 2018, 12, 495-504.

127. Ding, D.; Pan, Z.; Cuiuri, D.; Li, H. Wire-feed additive manufacturing of metal components: Technologies, developments and future interests. Int. J. Adv. Manuf. Technol. 2015, 81, 465-481.

128. Oropallo, W.; Piegl, L.A. Ten challenges in 3D printing. Eng. Comput. 2016, 32, 135-148.

129. Tilton, B.; Dobner, E.; Holdowsky, J. 3D Opportunity for Standards. Available online: https://www2.deloitte.com/us/en/ insights/focus/3d-opportunity/additive-manufacturing-standards-for-3d-printed-products.html\#endnote-sup-36 (accessed on 12 September 2019).

130. Klingaa, C.G.; Bjerre, M.K.; Baier, S.; De Chiffre, L.; Mohanty, S.; Hattel, J.H. Roughness Investigation of SLM Manufactured Conformal Cooling Channels Using X-ray Computed Tomography. In Proceedings of the 9th Conference on Industrial Computed Tomography (ICT 2019), Padova, Italy, 13-15 February 2019.

131. McGregor, D.J.; Tawfick, S.; King, W.P. Automated metrology and geometric analysis of additively manufactured lattice structures. Addit. Manuf. 2019, 28, 535-545.

132. Sagbas, B.; Boyac1, T.H.; Durakbasa, N.M. Precision metrology for additive manufacturing. In Proceedings of the International Symposium for Production Research 2017, Vienna, Austria, 13-15 September 2017; pp. 324-332.

133. Colosimo, B.M.; Huang, Q.; Dasgupta, T.; Tsung, F. Opportunities and challenges of quality engineering for additive manufacturing. J. Qual. Technol. 2018, 50, 233-252.

134. Qin, Y.; Qi, Q.; Scott, P.J.; Jiang, X. Status, comparison, and future of the representations of additive manufacturing data. Comput. Aided Des. 2019, 111, 44-64.

135. Lewandowski, J.J.; Seifi, M. Metal additive manufacturing: A review of mechanical properties. Annu. Rev. Mater. Res. 2016, 46, 151-186.

136. Shapiro, A.; Borgonia, J.; Chen, Q.; Dillon, R.; McEnerney, B.; Polit-Casillas, R.; Soloway, L. Additive manufacturing for aerospace flight applications. J. Spacecr. Rocket. 2016, 952-959. [CrossRef]

137. Herzog, D.; Seyda, V.; Wycisk, E.; Emmelmann, C. Additive manufacturing of metals. Acta Mater. 2016, 117, 371-392.

138. Almotairy, S.M.; Boostani, A.F.; Hassani, M.; Wei, D.; Jiang, Z. Effect of hot isostatic pressing on the mechanical properties of aluminium metal matrix nanocomposites produced by dual speed ball milling. J. Mater. Res. Technol. 2020, 9, 1151-1161.

139. Chen, C.; Xie, Y.; Yan, X.; Yin, S.; Fukanuma, H.; Huang, R.; Zhao, R.; Wang, J.; Ren, Z.; Liu, M. Effect of hot isostatic pressing (HIP) on microstructure and mechanical properties of Ti6Al4V alloy fabricated by cold spray additive manufacturing. Addit. Manuf. 2019, 27, 595-605.

140. Benzing, J.; Hrabe, N.; Quinn, T.; White, R.; Rentz, R.; Ahlfors, M. Hot isostatic pressing (HIP) to achieve isotropic microstructure and retain as-built strength in an additive manufacturing titanium alloy (Ti-6Al-4V). Mater. Lett. 2019, $257,126690$.

141. Horst, O.; Ruttert, B.; Bürger, D.; Heep, L.; Wang, H.; Dlouhý, A.; Theisen, W.; Eggeler, G. On the rejuvenation of crept Ni-Base single crystal superalloys (SX) by hot isostatic pressing (HIP). Mater. Sci. Eng. A 2019, 758, 202-214.

142. Hirata, T.; Kimura, T.; Nakamoto, T. Effects of hot isostatic pressing and internal porosity on the performance of selective laser melted AlSi10Mg alloys. Mater. Sci. Eng. A 2020, 772, 138713.

143. Kumar, A.; Bai, Y.; Eklund, A.; Williams, C.B. Effects of hot isostatic pressing on copper parts fabricated via binder jetting. Procedia Manuf. 2017, 10, 935-944.

144. Cai, C.; Song, B.; Xue, P.; Wei, Q.; Wu, J.-m.; Li, W.; Shi, Y. Effect of hot isostatic pressing procedure on performance of Ti6Al4V: Surface qualities, microstructure and mechanical properties. J. Alloy. Compd. 2016, 686, 55-63.

145. Tammas-Williams, S.; Withers, P.J.; Todd, I.; Prangnell, P.B. The effectiveness of hot isostatic pressing for closing porosity in titanium parts manufactured by selective electron beam melting. Metall. Mater. Trans. A 2016, 47, 1939-1946.

146. Bartlett, J.L.; Li, X. An overview of residual stresses in metal powder bed fusion. Addit. Manuf. 2019, $27,131-149$.

147. Prashanth, K.G.; Scudino, S.; Klauss, H.J.; Surreddi, K.B.; Löber, L.; Wang, Z.; Chaubey, A.K.; Kühn, U.; Eckert, J. Microstructure and mechanical properties of Al-12Si produced by selective laser melting: Effect of heat treatment. Mater. Sci. Eng. A 2014, 590, 153-160.

148. Oyelola, O.; Crawforth, P.; M'Saoubi, R.; Clare, A.T. Machining of additively manufactured parts: Implications for surface integrity. Procedia CIRP 2016, 45, 119-122.

149. Bhaduri, D.; Penchev, P.; Batal, A.; Dimov, S.; Soo, S.L.; Sten, S.; Harrysson, U.; Zhang, Z.; Dong, H. Laser polishing of 3D printed mesoscale components. Appl. Surf. Sci. 2017, 405, 29-46.

150. Zhihao, F.; Libin, L.; Longfei, C.; Yingchun, G. Laser polishing of additive manufactured superalloy. Procedia CIRP 2018, 71, 150-154.

151. Yung, K.; Zhang, S.; Duan, L.; Choy, H.; Cai, Z. Laser polishing of additive manufactured tool steel components using pulsed or continuous-wave lasers. Int. J. Adv. Manuf. Technol. 2019, 105, 425-440. 
152. Gu, J.; Ding, J.; Williams, S.W.; Gu, H.; Bai, J.; Zhai, Y.; Ma, P. The strengthening effect of inter-layer cold working and post-deposition heat treatment on the additively manufactured Al-6.3 Cu alloy. Mater. Sci. Eng. A 2016, 651, 18-26.

153. Cunningham, C.; Wikshåland, S.; Xu, F.; Kemakolam, N.; Shokrani, A.; Dhokia, V.; Newman, S. Cost modelling and sensitivity analysis of wire and arc additive manufacturing. Procedia Manuf. 2017, 11, 650-657.

154. Colegrove, P.A.; Donoghue, J.; Martina, F.; Gu, J.; Prangnell, P.; Hönnige, J. Application of bulk deformation methods for microstructural and material property improvement and residual stress and distortion control in additively manufactured components. Scr. Mater. 2017, 135, 111-118.

155. Krishnan, A.; Fang, F. Review on mechanism and process of surface polishing using lasers. Front. Mech. Eng. 2019, 1-21. [CrossRef]

156. Campbell, R.I.; Jee, H.; Kim, Y.S. Adding product value through additive manufacturing. In Proceedings of the 19th International Conference on Engineering Design (ICED13), Design for Harmonies, Volume 4: Product, Service and Systems Design, Seoul, Korea, 19-22 August 2013.

157. Knofius, N.; van der Heijden, M.C.; Zijm, W.H. Consolidating spare parts for asset maintenance with additive manufacturing. Int. J. Prod. Econ. 2019, 208, 269-280.

158. Seifi, M.; Salem, A.; Beuth, J.; Harrysson, O.; Lewandowski, J.J. Overview of materials qualification needs for metal additive manufacturing. JOM 2016, 68, 747-764.

159. King, W.E.; Anderson, A.T.; Ferencz, R.; Hodge, N.; Kamath, C.; Khairallah, S.A.; Rubenchik, A.M. Laser powder bed fusion additive manufacturing of metals; physics, computational, and materials challenges. Appl. Phys. Rev. 2015, $2,041304$.

160. Chew, Y.; Bi, G.; Zhu, Z.; Ng, F.; Weng, F.; Liu, S.; Nai, S.; Lee, B. Microstructure and enhanced strength of laser aided additive manufactured CoCrFeNiMn high entropy alloy. Mater. Sci. Eng. A 2019, 744, 137-144.

161. Yang, X.; Liu, J.; Cui, X.; Jin, G.; Liu, Z.; Chen, Y.; Feng, X. Effect of remelting on microstructure and magnetic properties of Fe-Co-based alloys produced by laser additive manufacturing. J. Phys. Chem. Solids 2019, 130, 210-216.

162. Bordeenithikasem, P.; Stolpe, M.; Elsen, A.; Hofmann, D.C. Glass forming ability, flexural strength, and wear properties of additively manufactured Zr-based bulk metallic glasses produced through laser powder bed fusion. Addit. Manuf. 2018, 21, 312-317.

163. Wu, D.; Gao, W.; Hui, D.; Gao, K.; Li, K. Stochastic static analysis of Euler-Bernoulli type functionally graded structures. Compos. Part B Eng. 2018, 134, 69-80.

164. Ryder, M.A.; Lados, D.A.; Iannacchione, G.S.; Peterson, A.M. Fabrication and properties of novel polymer-metal composites using fused deposition modeling. Compos. Sci. Technol. 2018, 158, 43-50.

165. Martin, J.H.; Yahata, B.D.; Clough, E.C.; Mayer, J.A.; Hundley, J.M.; Schaedler, T.A. Additive manufacturing of metal matrix composites via nanofunctionalization. MRS Commun. 2018, 8, 297-302.

166. Ngo, T.D.; Kashani, A.; Imbalzano, G.; Nguyen, K.T.; Hui, D. Additive manufacturing (3D printing): A review of materials, methods, applications and challenges. Compos. Part B Eng. 2018, 143, 172-196.

167. Pei, E.; Loh, G.H. Future challenges in functionally graded additive manufacturing. In Additive Manufacturing-Developments in Training and Education; Springer: Berlin/Heidelberg, Germany, 2019; pp. 219-228.

168. Simpson, T.W.; Williams, C.B.; Hripko, M. Preparing industry for additive manufacturing and its applications: Summary \& recommendations from a National Science Foundation workshop. Addit. Manuf. 2017, 13, 166-178.

169. Go, J.; Hart, A.J. A framework for teaching the fundamentals of additive manufacturing and enabling rapid innovation. Addit. Manuf. 2016, 10, 76-87.

170. Dutta, B.; Froes, F.H.S. The additive manufacturing (AM) of titanium alloys. In Titanium Powder Metallurgy; Elsevier: Amsterdam, The Netherlands, 2015; pp. 447-468.

171. Duda, T.; Raghavan, L.V. 3D metal printing technology. IFAC-PapersOnLine 2016, 49, 103-110.

172. Vafadar, A.; Tolouei-Rad, M.; Hayward, K.; Abhary, K. Technical feasibility analysis of utilizing special purpose machine tools. J. Manuf. Syst. 2016, 39, 53-62.

173. Kretzschmar, N.; Ituarte, I.F.; Partanen, J. A decision support system for the validation of metal powder bed-based additive manufacturing applications. Int. J. Adv. Manuf. Technol. 2018, 96, 3679-3690.

174. Sriram, V.; Shukla, V.; Biswas, S. Metal Powder Based Additive Manufacturing Technologies—Business Forecast. In 3D Printing and Additive Manufacturing Technologies; Springer: Berlin/Heidelberg, Germany, 2019; pp. 105-118.

175. Ulu, E.; Huang, R.; Kara, L.B.; Whitefoot, K.S. Concurrent Structure and Process Optimization for Minimum Cost Metal Additive Manufacturing. J. Mech. Des. 2019, 141, 061701.

176. Vafadar, A.; Hayward, K.; Tolouei-Rad, M. Sensitivity analysis for justification of utilising special purpose machine tools in the presence of uncertain parameters. Int. J. Prod. Res. 2017, 55, 3842-3861.

177. Li, Y.; Cheng, Y.; Hu, Q.; Zhou, S.; Ma, L.; Lim, M.K. The influence of additive manufacturing on the configuration of make-to-order spare parts supply chain under heterogeneous demand. Int. J. Prod. Res. 2019, 57, 3622-3641. 